\title{
Comparative study on effect of mechanical mixing and ultrasound on the performance of a single up-flow anaerobic/aerobic/anoxic bioreactor removing CNP from milk processing wastewater
}

\author{
S. Rezaee, A.A. Zinatizadeh ${ }^{*}$, A. Asadi \\ Water and Wastewater Research Center (WWRC), Department of Applied Chemistry, Faculty of \\ Chemistry, Razi University, Kermanshah, Iran \\ Email: zinatizadeh@gmail.com, zinatizadeh@razi.ac.ir
}


Keywords: Carbon and nutrients removal, up-flow anaerobic/anoxic/aerobic sludge bed, milk processing wastewater, ultrasonic irradiation, mechanical mixing. 


\begin{tabular}{|c|c|}
\hline \multicolumn{2}{|c|}{ Abbreviations } \\
\hline AFR & Anaerobic filter reactor \\
\hline AS & Activated sludge \\
\hline BOD & Biochemical oxygen demand \\
\hline CFID & Continuous feed and intermittent discharge \\
\hline CNP & Carbon, nitrogen and phosphorous \\
\hline COD & Chemical oxygen demand \\
\hline DO & Dissolved oxygen \\
\hline $\mathrm{F} / \mathrm{M}$ & Food to microorganism ratio \\
\hline HRT & Hydraulic retention time \\
\hline MLSS & Mixed liquor suspended solid \\
\hline MSBR & Membrane sequencing batch reactor \\
\hline MSBR & Sequencing batch reactor biofilm \\
\hline MPW & Milk processing wastewater \\
\hline OLR & Organic loading rate \\
\hline PAOs & Phosphorus accumulating organisms \\
\hline pCOD & Particulate COD \\
\hline PHP & Poly hydroxy butyrate \\
\hline RSM & Response surface methodology \\
\hline SBR & Sequential batch reactor \\
\hline SBFFBR & Sequencing batch flexible fibre biofilm reactor \\
\hline sCOD & Soluble COD \\
\hline $\mathrm{TN}$ & Total nitrogen \\
\hline TKN & Total kjeldahl nitrogen \\
\hline TP & Total phosphorus \\
\hline UASB & Up-flow anaerobic sludge blanket \\
\hline UAASB & Up-flow aerobic anoxic sludge bed \\
\hline UAAASB & Up-flow anaerobic/anoxic/aerobic sludge bed \\
\hline
\end{tabular}




\section{Introduction}

Nowadays, wastewater treatment has been a challenging problem throughout the world with increasing consciousness about water pollution. Discharging dairy industrial wastewater as a developed industry in recent years has threatened the precious aqueous environment due to its high chemical oxygen demand (COD) and nutrients (N\&P) content [1]. Different techniques have been investigated for treating a wide range of wastewaters such as biological treatment processes, membrane technology, advanced oxidation processes, coagulation and etc. Being more cost effective and effortless to operate, biological treatment is identified as a desired method to treat dairy wastewater [2]. Different bioreactors with different hydraulic regimes have been applied to treat dairy industrial wastewater over the years. As a review in continuous systems, an up-flow anaerobic sludge blanket (UASB) reactor followed by an activated sludge (AS) system was used for treating the combination of dairy and domestic wastewaters. $99.6 \%$ of COD removal efficiency was obtained at total HRT of $26 \mathrm{~h}$ (24 h for UASB and $2.0 \mathrm{~h}$ for AS system) and OLR of $3.4 \mathrm{~kg} \mathrm{COD} / \mathrm{m}^{3} . \mathrm{d}[3]$. Omil and his coworkers reported higher than $90 \%$ of COD removal efficiency at OLR of 5-6 kg COD/m $\mathrm{m}^{3} . \mathrm{d}$ in an anaerobic filter reactor (AFR) coupled with a sequential batch reactor (SBR) to treat dairy wastewater [4]. In another study, a hybrid UASB was employed for treating dairy wastewater and 93\% COD removal efficiency was obtained [5].

Besides continuous systems, SBR has been recognized as an efficient and controllable alternative to treat different wastewaters with its special advantages including easy operation, low investment and operation cost. SBR has been modified in different ways during the years. A membrane sequencing batch reactor (MSBR) system was used to treat dairy industrial wastewater and was able to remove $98 \% \mathrm{BOD}$ at $36 \mathrm{~h}$ and $0.22 \mathrm{~kg} \mathrm{BOD} / \mathrm{kg}$ MLSS.d [6]. Also, an aerobic sequencing batch flexible fiber biofilm reactor (SBFFBR) was 
operated for the treatment of milk processing wastewater and 97\% COD removal efficiency was achieved at OLR of $2.74 \mathrm{~kg} \mathrm{COD} / \mathrm{m}^{3} . \mathrm{d}$ and HRT of 1.6 days [7]. Sirianuntapiboon et al. reported the treatment of milk industrial wastewater with 97.9 and $79.3 \%$ for COD and total Kjeldahl nitrogen (TKN) removal efficiencies, respectively, at OLR of $0.68 \mathrm{~kg} \mathrm{BOD} / \mathrm{m}^{3} . \mathrm{d}$ in a sequencing batch reactor biofilm system [8].

Recently, a new generation of SBR was introduced as a high rate bioreactor to treat wastewater designed with continuous feeding and intermittent discharge (CFID) regime. CFID bioreactor has both advantages of continuous and batch systems. Asadi and her colleagues studied simultaneous carbon and nutrients removal from an industrial estate wastewater in an up-flow aerobic/anoxic sludge bed (UAASB) bioreactor based on CFID regime. The results showed 93 and $60 \%$ as COD and TN removal efficiencies, respectively, at optimum condition with HRT of $12 \mathrm{~h}$ and aeration of $40 \mathrm{~min} / \mathrm{h}$ [9].

High concentration of mixed liquor suspended solid (MLSS) in bioreactors is key factor affecting treatment capacity of the biological processes and consequently reducing volume and energy consumption. On the other side, high MLSS concentration in bioreactors could create some troubles for the sludge sedimentation and separation [10]. The membrane bioreactors have been introduced as a solution for trouble shooting of high MLSS concentration in the recent researches. Besides that, another strategy for controlling high concentration of biomass is to use ultrasonic irradiation with suitable frequency [11].

Three ranges of frequency has been reported for three distinct uses of the ultrasound including: (1) high-frequency ultrasound (1-10 MHz), (2) low-frequency ultrasound (20-100 $\mathrm{kHz}$ ), and (3) medium-frequency ultrasound (300-1000 kHz) [12]. Applying the ultrasound 
with low frequency creates larger cavitation bubbles and stronger hydrodynamic shear forces. So, this frequency usually used for sludge disintegration [13]. The ultrasound with medium frequency has sonochemical effects that promotes chemical reaction processes through very "excessive" temperatures and pressures created by cavitation bubbles [14]. The highfrequency ultrasonic irradiation lead to bubbles with smaller size and steadier that called stable cavitation [15]. Stable cavitation provides a better mass transfer of liquid media into solid surfaces and vice versa.

In an earlier study performed by the authors [16], an up-flow anaerobic/ anoxic/ aerobic sludge bed (UAAASB) derived from CFID SBR design augmented with high-frequency ultrasonic irradiation was operated to remove nutrients from milk processing wastewater. The anaerobic, anoxic and aerobic conditions were applied by adjusting aeration time. Moreover, the ultrasonic irradiation was applied at the anoxic and anaerobic phases to provide required mixing into the bioreactor. The results from this study showed that the sludge settling velocity and effluent turbidity were remarkably improved with the ultrasonic irradiation. Also, the UAASB bioreactor demonstrated a good performance in removing nitrogen and phosphorus.

In this study, in order to explore the role of the high-frequency ultrasonic irradiation in the process, the UAAASB was operated treating milk processing wastewater under two mixing modes, i.e., with mechanical mixing and with sonication. The process performance in removing

carbon and nutrients $(\mathrm{N} \& \mathrm{P})$ at the two mixing conditions was compared. In addition, the effects of three operating independent variables (MLSS concentration, HRT and aeration mode) were studied and also the optimum conditions in both mixing modes were determined. 


\section{Materials and methods}

\subsection{Preparation of milk processing wastewater}

The milk processing wastewater was taken from a working dairy plant, Sahra Co., Kermanshah, Iran. The samples were stored in a refrigerator at $4{ }^{\circ} \mathrm{C}$ to prevent any change in the matrix of samples. The characteristics of Sahra's dairy wastewater are shown in Table 1. It should be mentioned the real phosphorus concentration in the samples was about 5-6 mg/l. In order to determine the maximum capacity of the systems for removing phosphorus, the phosphorus concentration was fixed at $50 \mathrm{mg} / \mathrm{l}$ by adding $\mathrm{KH}_{2} \mathrm{PO}_{4}$ so that the ratio of COD: $\mathrm{N}$ : P was about 100: 18: 5.

\subsection{Bioreactor configuration}

The schematic diagram of both up-flow anaerobic/anoxic/aerobic sludge bed (UAAASB) bioreactors is shown in Fig. 1. As shown in the Fig., two bioreactors were the same in terms of volume, dimension and geometry, except that one of them had a mechanical mixer while another reactor was mixed using an ultrasonic transducer. The glass columns were fabricated with an internal diameter of $8 \mathrm{~cm}$, a liquid height of $100 \mathrm{~cm}$ and a total volume of $5 \mathrm{~L}$. In order to attain the intermittent discharge, two automatic control valves were mounted in the middle of the columns. The bioreactors were aerated with two air bubble diffusers connected with an air blower.

The ultrasonic transducer powered by a piezoelectric ultrasonic transducer (Model ANN2517GRL, ANNON PIEZO TECHNOLOGY CO. LTD, China), with frequency of $1.7 \mathrm{MHz}$.

\subsection{Process modeling and optimization}

Response surface methodology (RSM) is a collection of mathematical and statistical techniques useful for analyzing the effects of several independent variables on the response. 
RSM has an important application in the process design and optimization as well as the improvement of existing design. This methodology is an approach as it arises from experimental methodology which includes interactive effects among the variables. Eventually, it depicts the overall effects of the parameters on the process. RSM offers a large amount of information from a small number of experiments. Indeed, classical methods are time consuming and a large number of experiments are needed to explain the behavior of a system.

There are many classes of response surface designs that are occasionally useful in practice such as Central Composite design, Box-Behnken design, Hybrid design and Three-level Factorial design. The Central Composite Design (CCD) is the most frequently used under RSM design. The design consists of $2 \mathrm{k}$ factorial points augmented by $2 \mathrm{k}$ axial points and a center point where $\mathrm{k}$ is the number of variables. The levels of each variable vary from a low to high value which are numerically expressed or coded as -1 and 1 . Intermediate level is coded as 0 .

\subsection{Experimental design and mathematical modeling}

The bioreactors (with mechanical mixer and with an ultrasonic transducer) were operated in the same conditions. Statistical design of the experiments and data analysis were carried out by Design Expert Software (version 7.0). Three independent effective variables (HRT, MLSS concentration, and aeration mode) were selected to design the experiments. The range and levels of the variables in coded and actual units are given in Table 2. The three operating variables were considered at three levels. In the basis of the factorial design, 20 experiments (including 8 factorial points, 6 axial points, 1 center point and 5 replications of the center point) were designed. sCOD removal, TN removal, TKN removal, denitrification rate, effluent nitrate, effluent nitrite, TP removal, effluent turbidity, SVI were measured or 
calculated as responses in both bioreactors. The experimental conditions and results are shown in Tables 3 and 4. The experimental data obtained was used to determine the coefficients of the polynomial model (Eq. 1), Khuri and Cornell [17].

$$
Y=\beta_{0}+\beta_{i} X_{i}+\beta_{j} X_{j}+\beta_{i i} X_{i}^{2}+\beta_{j j} X_{j}^{2}+\beta_{i j} X_{i} X_{j}+\ldots
$$

Where, $i$ and $j$ are the linear and quadratic coefficients, respectively, and $\beta$ is the regression coefficient. P value with $95 \%$ confidence level was considered to evaluate the effectiveness of the model terms.

\subsection{Bioreactor operation}

The milk processing wastewater (MPW) was continuously pumped into the bioreactors from the bottom of the columns, but the treated effluent was intermittently discharged in the middle of columns at the end of each run. The UAAASB bioreactors were operated under room temperature $\left(20 \pm 2^{\circ} \mathrm{C}\right)$. Dissolved oxygen (DO) in the UAAASB bioreactors was kept in the range of $2.8-4.2 \mathrm{mg} / \mathrm{l}$ at all aeration periods. The anaerobic, anoxic, and aerobic conditions were provided by controlling aeration time. The ultrasonic irradiation and mechanical mixer were applied at the settling periods in the bioreactors.

In the first stage (bioreactor start-up), the bioreactors were operated at HRT, MLSS concentration, and aeration mode of $6 \mathrm{~h}, 7000 \mathrm{mg} / \mathrm{l}$ and 2, respectively, for one month to achieve a steady-state condition. In the second stage, the bioreactors were operated according to the experimental runs which were designed by Design Expert software as shown in Tables 3 and 4 . In this study, three independent effective variables i.e. HRT $(6,12,18 \mathrm{~h})$, aeration time ratio $(1,1.5,2)$ and MLSS content $(4000,7000,10000 \mathrm{mg} / \mathrm{l})$ were studied in both bioreactors. It must be noted that all the experimental runs were started with anaerobic 
condition then aerobic and anoxic conditions were repeated continuously according to the aeration strategy (Table 5).

In the third stage, validity of the obtained model was verified by operating the ultrasoundmixed UAAASB under two different conditions recognized as the optimal conditions (MLSS: $5000 \mathrm{mg} / \mathrm{l}$, HRT: $12 \mathrm{~h}$, aeration mode: 1.5 and MLSS: $4000 \mathrm{mg} / \mathrm{l}, \mathrm{HRT}$ : $15 \mathrm{~h}$, aeration mode: 2 ).

\subsection{Analytical procedure}

The concentrations of COD, TN, TKN, nitrate, nitrite, $\mathrm{NH}_{4}-\mathrm{N}, \mathrm{TP}, \mathrm{MLSS}$ and SVI were determined by using standard methods [18]. Organic nitrogen was measured by deducing the ammonia nitrogen from TN. For SCOD, a colorimetric method with closed reflux method was developed. Spectrophotometer (DR 5000, Hach, Jenway, USA) at $600 \mathrm{~nm}$ was used to measure the absorbance of COD samples. Biological oxygen demand (BOD) was measured with BOD meter model (OxiTop IS 6). TKN and $\mathrm{N}-\mathrm{NH}_{4}$ were determined by TKN meter Gerhardt model (Vapodest 10, Germany). The DO concentration in the bioreactors was determined using a DO probe. DO meter was supplied by WTW DO Cell OX 330, electro DO probe, Germany. Turbidity was measured by a turbidity meter model 2100 P (Hach Co., USA).

\section{Results and discussion}

\subsection{Process performance}

\subsubsection{COD removal}


In milk processing industry, pCOD content is removed by physical methods such as flotation and screening. Hence, the pCOD was separated by filtration before use in the bioreactors [19]. Therefore, in order to compare the performance of the systems, sCOD removal was considered as a response. The ANOVA values for sCOD removal efficiency are shown in Table 6. The significance of each coefficient was determined by F-value and P-value. From Table 6, A (MLSS), B (HRT) and C (aeration mode), $\mathrm{B}^{2}, \mathrm{AB}$ and AC were significant model terms for the UAAASB with ultrasonication while the terms for the bioreactor with mechanical mixer were $\mathrm{A}, \mathrm{B}, \mathrm{C}, \mathrm{A}^{2} \mathrm{C}, \mathrm{AB}^{2}$ and $\mathrm{ABC}$. Other model terms were not significant.

Figures $2 \mathrm{a}$ and $\mathrm{b}$ illustrate the effects of the variables on the response in the UAAASB with ultrasonication and with mechanical mixer, respectively. From the Figs., both systems presented a similar performance in removing sCOD. It is clearly shown that the changing trends of sCOD removal efficiency as a function of MLSS and HRT are similar at different aeration modes for each bioreactor. The Figures display a decreasing effect of HRT on the response at high values of MLSS content at all aeration modes. Also, the similar decreasing trend in SCOD removal was observed with an increase in MLSS at high values of HRTs. It might be because of a reduction of F/M from 1 to $0.133 \mathrm{~g} \mathrm{COD/g} \mathrm{VSS.d} \mathrm{as} \mathrm{HRT} \mathrm{and} \mathrm{MLSS}$ content were increased. Besides, aeration mode had a positive effect on sCOD removal efficiency, so that the changes in aeration mode from 1 to 2 increased the maximum predicted sCOD removal efficiency by about $11 \%$ in the ultrasound-mixed UAAASB. Likewise, around $8 \%$ of increasing in the response was achieved with changing the aeration mode from 1 to 1.5 in the UAAASB with mechanical mixing. The reason could be attributed to higher oxidation potential as a result of higher aeration time. 
The maximum predicted sCOD removal efficiency was $99.8 \%$ for the ultrasound-mixed UAAASB in the condition with HRT of $18 \mathrm{~h}$, MLSS of $4000 \mathrm{mg} / \mathrm{l}$ (corresponding to F/M ratio of $0.33 \mathrm{~g} \mathrm{COD/g} \mathrm{VSS.} \mathrm{d)} \mathrm{and} \mathrm{aeration} \mathrm{mode} \mathrm{of} 2$. At the same condition, in the UAAASB with mechanical mixing, the maximum predicted sCOD removal efficiency was $97.78 \%$. It should be mentioned that, in this bioreactor, the effect of aeration mode at the values of 1.5 and 2 was identical.

To compare with the literature, Amini and her coworkers reported $98 \%$ as the maximum sCOD removal efficiency obtained in an upflow aerobic/ anoxic sludge bed reactor treating dairy wastewater at aeration time of $40 \mathrm{~min} / \mathrm{h}$ [20]. Also, similar result (sCOD removal of more than 95\%) was obtained from the working wastewater treatment plant (WWTP), Bistoon's dairy factory, Kermanshah-Iran. The WWTP consists of an anaerobic fixed bed followed by an activated sludge system, with HRT of $72 \mathrm{~h}$. This difference between the UAAASB and the WWTP in terms of required HRT corroborates that the UAAASB acts as a high rate bioreactor. It is also noted that the CFID regime applied in the UAAASB was an effective parameter by providing different dilution rate over a HRT.

Another result which can be presented is no determinable effect of the high-frequency ultrasonic irradiation on COD removal efficiency, denoting that the biological activity was not deteriorated by the high frequency ultrasonic irradiation. The similar result was reported by Zinadini et al. [11].

\subsubsection{Nitrogen removal}

\section{- TN removal}

In biological nitrogen removal, aerobic and anoxic periods and their ratios at a certain operating condition are one of the most important factors for nitrification and denitrification 
processes [21]. Nitrification process is attained by autotrophic nitrifying bacteria in aerobic zones and denitrification process is taken place by heterotrophic denitrifying bacteria in anoxic zones [22]. In this study, a range of aeration/non-aeration conditions were examined for nitrogen removal in both systems and their performance were compared.

The ANOVA values of TN removal for both systems are illustrated in Table 6. TN removal efficiency as a function of HRT and MLSS at three aeration modes is shown in Figs. 3a (for ultrasonic mixing) and $3 b$ (for mechanical mixing). As can be seen in the Figs., the variation of the response as a function of HRT and MLSS concentration showed almost same trend at all aeration modes applied. TN removal in both systems was decreased with increasing HRT in the range of MLSS concentration studied. Furthermore, at the lowest value of HRT (6 h) with increasing MLSS concentration from 4000 to $10000 \mathrm{mg} / \mathrm{l}$, the response was decreased at three aeration modes. It was attributed to a reduction in $\mathrm{F} / \mathrm{M}$ ratio, which leads to a limitation in the accessibility of microorganisms to carbon source in anoxic zones [23].

As a result, the maximum TN removal efficiency was achieved at the lowest values of MLSS concentration and HRT (4000 mg/l and $6 \mathrm{~h}$, respectively) in both systems. In this condition, F/M ratio is in its highest value $(1 \mathrm{~g} \mathrm{COD} / \mathrm{g}$ VSS.d). From Figs. $3 \mathrm{a}$ and b, the maximum TN removal efficiencies $(83.76 \%$ for the ultrasound-augmented UAAASB and $57.87 \%$ for the UAAASB with mechanical mixing) were obtained at the aeration modes of 1.5 and 2 . This result proves a good balance between aerobic and anoxic phases for nitrogen removal at the aeration modes of 1.5 and 2 . At the aeration mode of 1 , TN removal efficiency was lower than other aeration modes in both bioreactors, indicating insufficient aeration phase for nitrification process at this aeration mode. 


\begin{abstract}
Also, from the results presented in Tables 3 and 4, the maximum denitrification rate $(0.38$ gN/l.d in the UAAASB mixed by ultrasound and $0.23 \mathrm{gN} / \mathrm{l} . \mathrm{d}$ in the UAAASB with mechanical mixing) was obtained at the highest F/M ratio (1 g COD/g VSS. d) in both bioreactors similar to $\mathrm{TN}$ removal efficiency.
\end{abstract}

In a similar study, an up-flow anaerobic/ anoxic/ aerobic fluidized sludge bed bioreactor was operated for treating a synthetic wastewater (sucrose) and $79.3 \% \mathrm{TN}$ removal was reported at $35 \mathrm{~min} / \mathrm{h}$ as aeration time and HRT of $6.5 \mathrm{~h} \mathrm{[24].} \mathrm{It} \mathrm{should} \mathrm{be} \mathrm{noted} \mathrm{that} \mathrm{the} \mathrm{maximum}$ denitrification rate in the UAAASB with ultrasound was obtained at the aeration modes of 1.5 and 2 while in the UAAASB mixed by mechanical mixer, aeration mode had no effect on the response. The better performance of the ultrasound-mixed UAAASB in TN removal and denitrification rate relative to the reactor with mechanical mixing confirm that the ultrasonic irradiation has been more effective by providing a good mixed bulk in the bioreactor, reducing mass transfer resistance between bulk and microorganisms as well as stimulating enzyme activity and biosynthesis [25, 26].

\title{
- Fate of nitrogen compounds
}

In the biological nitrogen removal process, N-organic is bio-transformed into ammonia, nitrite, and then to nitrate (nitrification) in aerobic zones [27]. In anoxic zones, nitrate is reduced to nitrogen gas (denitrification) [28]. So, in this study, the concentrations of Norganic, $\mathrm{NH}_{4}^{+}, \mathrm{NO}_{2}^{-}, \mathrm{NO}_{3}^{-}$were determined throughout the experiments. The column diagrams of nitrogen constitutes for both UAAASB bioreactors are shown in Figs. 4a and b, respectively. 
As it is clear in Figs. 4a and b, effluent nitrite concentrations were not detectable in all the experiments due to complete nitrification process. Besides, effluent nitrate concentrations in the UAAASB with ultrasonic mixing were lower than those in the UAAASB with mechanical mixing which was related to the more denitrification process in the ultrasoundaugmented UAAASB. It was reported in the literature that the denitrification process is influenced by the ultrasonic irradiation more than the nitrification process by reason of their specific cell membrane and metabolism ways, so that denitrifying bacteria have the higher maximum specific growth rate compared to nitrifying bacteria [29]. Another result from Fig. 4a is the transformation of N-organic concentration into N-ammonia in the UAAASB with ultrasonic mixing which could be seen in the run numbers of 14 and 15 . Consequently, Norganic compounds were firstly converted to ammonia and then the nitrification process has been occurred.

In the mechanical-mixed UAAASB, the transformation of $\mathrm{N}$-organic into $\mathrm{N}$-ammonia was lower than the ultrasound-mixed UAAASB, in spite of an increase in the effluent ammonia concentrations relative to the influent at the run numbers of 14 and 15 .

\subsubsection{Phosphorus removal}

In order to have a biological phosphorus removal process, polyphosphate accumulating organisms (PAOs) are essential, which take up excess phosphorus in aerobic zones as long as they have previously accumulated enough poly hydroxy butyrate (PHB) in anaerobic zones [30]. In this study, both aerobic and anaerobic zones were provided in a single bioreactor. In order to evaluate the performance of the ultrasonic irradiation and the mechanical mixer to progress the availability of food to microorganisms, TP removal was monitored as a response. The variation of TP removal efficiency as a function of variables in the UAAASB 
mixed by ultrasound and mechanical mixer was described by reduced quadratic and cubic models, respectively. From Table 6, A, B, C, $\mathrm{A}^{2}, \mathrm{~B}^{2}, \mathrm{AC}, \mathrm{BC}, \mathrm{AB}^{2}$ and $\mathrm{ABC}$ were significant model terms for the ultrasound-mixed UAAASB while the terms for the reactor equipped with mechanical mixer were $\mathrm{A}, \mathrm{B}, \mathrm{C}, \mathrm{C}^{2}, \mathrm{AB}$ and AC. Figs. 5a (the ultrasound-mixed UAAASB) and 5b (the UAAASB with mechanical mixing) depict interactive effects of MLSS concentration and aeration mode on TP removal at different HRTs.

In the ultrasound-mixed UAAASB, TP removal efficiency showed a decreasing trend with an increase in aeration modes, indicating a limitation in the anaerobic zone at the higher aeration modes. From Fig. 5a, HRT had no significant effect on the response. In the system with mechanical mixing (Fig. 5b), TP removal decreased by an increase in MLSS concentration from 7000 to $10000 \mathrm{mg} / \mathrm{l}$. It should be noted that the decreasing trend in the response at HRT of $18 \mathrm{~h}$ was from 4000 to $7000 \mathrm{mg} / \mathrm{l}$ of MLSS concentration. Maximum TP removal efficiency obtained $70.11 \%$ and $57.47 \%$ in the ultrasound-mixed UAAASB and the UAAASB with the mechanical mixer, respectively at MLSS concentration of $7000 \mathrm{mg} / \mathrm{l}$, HRT of $6 \mathrm{~h}$ and aeration mode of 1 in both systems. From the Figures, an increase in TP removal is observed at HRTs of 6 and $12 \mathrm{~h}$ as a result of increasing MLSS concentration from 4000 to $7000 \mathrm{mg} / \mathrm{l}$, whereas a further increase in the MLSS concentration indicated a negative effect on the response. The reason for that might be a reduction in the $\mathrm{F} / \mathrm{M}$ ratio at the high values of MLSS concentration. Also, an increase in aeration modes from 1 to 2 in HRTs of 6 and $12 \mathrm{~h}$ caused a decrease in the response, implying a decrease in the anaerobic zone. It must be mentioned that in the UAAASB with mechanical mixing at the highest HRT (18 h), the impact of aeration mode could be negligible due to a restriction in carbon source. 
As a result, the ultrasound-augmented UAAASB showed a better performance in removing TP compared to the reactor with mechanical mixing which can be related to the positive effect of the ultrasonic irradiation on the growth and activity of PAOs in the anaerobic phase [31]. It has been reported that the ultrasonic irradiation could facilitate the anaerobic up taking of organic substrates by modifying cellular metabolisms of PAOs [32]. Therefore, the phosphorus release and absorption processes under the anaerobic and aerobic conditions might be enhanced by the ultrasonic irradiation.

\subsubsection{Effluent turbidity}

Turbidity is a physical parameter to assess the process performance. Thus, in this study, effluent turbidity was measured as a response and the results are presented in Tables 3 and 4. From the tables, the range of the effluent turbidity obtained was 2-16 NTU for the ultrasoundmixed UAAASB and 7-22 NTU for the UAAASB with mechanical mixing. In both systems, the maximum effluent turbidity was reported at run number 1 with the highest F/M ratio and the lowest aeration mode ( $1 \mathrm{~g}$ COD/g VSS.d and 1, respectively). Also, according to data obtained, by increasing the aeration mode from 1 to 2 at the similar F/M ratio $(0.28 \mathrm{~g} \mathrm{COD} / \mathrm{g}$ VSS) the effluent turbidity was decreased in both systems which was attributed to more microbial aggregation at higher oxidation potential (run numbers 7, 8, and 9). Asadi and her colleagues have reported the similar results, so that the minimum predicted effluent turbidity (14 NTU) was observed at the highest aeration time (60 $\mathrm{min} / \mathrm{h})$ [9]. Generally, the ultrasoundmixed UAAASB presents better clarification relative to the UAAASB with mechanical mixing due to providing a suitable vibration in the bulk of sludge created by the highfrequency ultrasonic irradiation. From the literature, it was found that the vibration improves the aggregation of small particles to form large flocs and subsequently, the particles will be large enough to settle down properly [33]. 


\subsubsection{Sludge characteristics}

\section{- $\quad$ Sludge volume index (SVI)}

Sludge bulking and floating is a big concern in many wastewater treatment plants [34]. In this mean, sludge volume index (SVI) was monitored as a response throughout the experiments. The SVI data obtained in both systems was fitted with two modified quadratic models. From Table $6, \mathrm{~A}, \mathrm{~B}, \mathrm{C}, \mathrm{B}^{2}, \mathrm{AB}$, and $\mathrm{BC}$ were significant model terms for both bioreactors. From the equation, aeration mode had the least effect compared to other variables studied. The variations of SVI as a function of MLSS concentration and HRT at different aeration modes for the ultrasound-mixed UAAASB and the UAAASB with mechanical mixing are shown in Figs. 6a and b, respectively. From the results, the range of the response obtained was 71.69$116.37 \mathrm{ml} / \mathrm{g}$ and $77.42-119.06 \mathrm{ml} / \mathrm{g}$, respectively, for the ultrasound-mixed UAAASB and the mechanical-mixed UAAASB bioreactor. The Figures showed that the variation of the response was almost similar in the bioreactors. The maximum SVI value in both systems was observed at the highest and lowest values of F/M ratio, representing the damaging effects of both feast and famine conditions on the sludge settling ability by upsetting the balance between growth and decay rates of cells.

The minimum SVI value obtained was $71.69 \mathrm{ml} / \mathrm{g}$ in the UAAASB with ultrasonic transducer and $77.41 \mathrm{ml} / \mathrm{g}$ in the UAAASB with mechanical mixing when MLSS concentration, aeration mode, and HRT were $10000 \mathrm{mg} / \mathrm{l}, 2$, and $6 \mathrm{~h}$, respectively. This result verifies the improving effect of the ultrasound on the sludge settling ability.

\section{- Height of sludge in the bioreactor}

The effect of the high-frequency ultrasonic irradiation on the height of sludge at the settling period of different experimental conditions was illustrated in Fig. 7. As can be seen in the Fig., the ultrasonic irradiation provided less sludge height compared to the UAAASB without 
ultrasound, demonstrating a significant enhancing effect of ultrasound on the settling velocity of the sludge [35]. It was accepted that a stable cavitation and an important fluid hydrodynamic effect named micro streaming could be created in the fluid by the highfrequency ultrasonic irradiation [36]. These phenomena generate a fluid movement at along of transducer axis by the name of acoustic fountain since they hit the upper surface and return to the fluid improving the microbial flocculation and afterward shorten the settling time with the low height of sludge in the bioreactor [37].

From the Figure, the shortest sludge height was achieved at MLSS concentration, HRT and aeration mode of $4000 \mathrm{mg} / \mathrm{l}, 18 \mathrm{~h}$, and 2, respectively (run no. 5). This result can be explained by two reasons; one is related to the low concentration of MLSS that favored settling velocity. Another main reason which caused a good flocculation of the sludge is the appropriate ratio of F/M (0.33 g COD/g VSS. d) in the conditions with $4000 \mathrm{mg} / \mathrm{l} \mathrm{MLSS}$ concentration. In addition, by increasing the MLSS concentrations from 4000 to $10000 \mathrm{mg} / \mathrm{l}$, the height of sludge was increased as the type of settling mechanism was changed to hindered settling at this high MLSS concentration [38]. At the MLSS concentrations higher than 7000 $\mathrm{mg} / \mathrm{l}$ (at the UAAASB with mechanical mixing), the height of sludge was above the outlet level, indicating sludge wash out, in contrast to the ultrasound-mixed UAAASB.

\subsection{Process optimization and verification}

Figure 8a shows the graphical optimization for the ultrasound-mixed UAAASB, which displays the areas of feasible response values (shaded portion) in the factors space. The optimum regions were identified in the Fig., based on four critical responses (sCOD removal, TN removal, TP removal and SVI). The shaded areas on the overlay plot in Fig. 8a are the regions that meet the proposed criteria presented in Table 7. From Figure 8a, the aeration 
modes of 1.5 and 2 demonstrate the optimal region as a result of a general balanced anaerobic (for TP removal), anoxic (for denitrification) and aerobic (for nitrification and COD removal) phases. As demonstrated in the Fig., the optimum region was restricted by the MLSS concentrations higher than $6000 \mathrm{mg} / \mathrm{l}$ at all the aeration modes. As a result, the optimum conditions were found to be at HRTs of 12-15 $\mathrm{h}$ and MLSS concentrations of 4000-5500 mg/l at aeration modes of 1.5 and 2. Furthermore, to verify the accuracy of the proposed models, two points within the optimum regions were selected (the conditions are shown in Fig. 8a) and then the bioreactor was operated under the operating conditions to compare the actual data with the predicted values obtained from the models. Table 8 presents the real data of two experiments within the optimum regions (Fig. 8a). The standard deviation for each response verifies the accuracy of the optimum condition as shown in Table 8 . From the table, the real data was in close agreement with the predicted values.

Additionally, the same criteria were applied to achieve graphical optimization for the UAAASB with mechanical mixing as shown in Fig. 8b. From the Figure, the optimum region was not appeared at the UAAASB with mechanical mixing. As a conclusion, the ultrasoundmixed UAAASB showed a better performance in the simultaneous removal of CNP compared to the UAAASB with mechanical mixing.

\subsection{Economical assessment}

In the last two decades, the consumption of energy has markedly increased as a result of the increasing world population and rapid technological development [39]. Therefore, the value of energy consumption is considered as a key point to develop a technology to industries. Hence, in order to meet the practical needs of industries, new bioreactors involved financial considerations must be developed [40]. Two main factors affecting the process economic can 
be reactor volume and energy consumption. As illustrated in the optimization section, the UAAASB augmented by the ultrasonic irradiation showed higher performance rather than the UAAASB with mechanical mixer, implying on less required volume for the bioreactor augmented by ultrasound which directly reduces the capital costs and subsequently affects the other associated costs.

As we are introducing ultrasound application instead of mechanical mixer in this study, energy consumption as another aspect of economical assessment is estimated. In this mean, the optimal operating condition obtained from the UAAASB with the ultrasonic irradiation was considered as the calculation basis. Based on the optimal condition, the economical evaluation was done at the aeration modes of 1.5 and 2 with the ultrasonic irradiation of 24 and $20 \mathrm{~min} / \mathrm{h}$, respectively. The energy demands (ED) to provide the ultrasonic irradiation for each cubic meter of wastewater was calculated based on the following equation:

$$
E D=P . t
$$

where, $\mathrm{P}$ is power $(\mathrm{W})$, and $\mathrm{t}$ is the time of irradiation (h). As the power of the ultrasonic inducer used in this study was $9.5 \mathrm{~W}$ (in the basis of the working volume of the bioreactor (2.5 lit)), the values of ED is calculated to be 1520 and $1254 \mathrm{~W} / \mathrm{m}^{3} \cdot \mathrm{h}$, respectively for the aeration modes of 1.5 and 2 . While, the power of the used mechanical mixer in the UAAASB with mechanical mixing was $36 \mathrm{~W}$. In this basis, the values of ED are calculated as 5760 and $4752 \mathrm{~W} / \mathrm{m}^{3} . \mathrm{h}$ for the aeration modes of 1.5 and 2 , respectively. Consequently, operating of the UAAASB with ultrasonic irradiation is more cost effective than the UAAASB with mechanical mixer as the ultrasonic irradiation requires about $25 \%$ of the energy consumed by the mechanical mixer. Therefore, the high frequency ultrasonic irradiation can be suggested as a promising alternative to upgrade the biological treatment wastewater plants through 
reducing the cost of construction and operating along with an increasing effect on the performance.

\section{Conclusion}

In this study, in order to evaluate the effect of the high-frequency ultrasonic irradiation, the UAAASB was operated in two ways, (1) with ultrasonication and (2) with mechanical mixer. Both bioreactors were operated at the same experimental conditions and their performances in the treatment of MPW were compared. From the results, the ultrasound-mixed UAAASB showed a better performance in removing carbon and nutrients from milk processing wastewater relative to the UAAASB with mechanical mixing. The models derived from RSM could predict the studied responses as a function of the variables (MLSS, HRT and aeration mode) with a good agreement with the actual data. From the models, an optimum condition in the bioreactor with ultrasonic irradiation was found at HRTs of 12-15 h, MLSS concentrations of 4000-5000 mg/l, and aeration modes of 1.5 and 2. As a conclusion, the high-frequency ultrasonic irradiation $(1.7 \mathrm{MHz})$ could enhance the process performance in terms of sCOD removal, TN removal, TP removal, and reduce the effluent turbidity and the height of sludge in the bioreactor. As a conclusion, the high frequency ultrasonic irradiation can be suggested as a promising alternative to upgrade the biological treatment wastewater plants through reducing the cost of construction and operating along with an increasing effect on the performance.

\section{Acknowledgment}

The authors would like to acknowledge Iran National Science Foundation (INSF) (No: 92/ S/31972) for the full financial support provided for this research work. Special thanks go to Professor Masoud Rahimi for his scientific advices in this project. The authors also wish to 
thank Mrs. F. Ghadami, Mrs. S. Zarabi, Mrs. S. Kiani, Mr. S. Ghanbari, and Miss K. Aftabi for their kind assistance.

\section{References}

[1] Su Y, Mennerich A, Urban B. Coupled nutrient removal and biomass production with mixed algal culture: Impact of biotic and abiotic factors. Bioresour Technol 2012;118:469-476.

[2] Carvalho F, Prazeres AR, Rivas J. Cheese whey wastewater: Characterization and treatment. Sci Total Environ 2013;445-446:385-396.

[3] Tawfik A, Sobhey M, Badawy M. Treatment of a combined dairy and domestic wastewater in an up-flow anaerobic sludge blanket (UASB) reactor followed by activated sludge (AS system). Desalination 2008;227:167-177.

[4] Omil F, Garrido JM, Arrojo B, Mendez R. Anaerobic filter reactor performance for the treatment of complex dairy wastewater at industrial scale. Water Res 2003;37:4099-4108.

[5] Gomes DRS, Papa LG, Cichello GCV, Belançon D, Pozzi EG, Balieiro JCC, Monterrey-Quintero ES, Tommaso G. Effect of enzymatic pretreatment and increasing the organic loading rate of lipid-rich wastewater treated in a hybrid UASB reactor. Desalination 2011;279:96-103.

[6] Bae T-H, Han S-S, Tak T-M. Membrane sequencing batch reactor system for the treatment of dairy industry wastewater. Process Biochem 2003;39:221-231.

[7] Abdulgader M, Yu QJ, Zinatizadeh AA, Williams P. Biological treatment of milk processing wastewater in a sequencing batch flexible fibre biofilm reactor. Asia-Pac J Chem Eng 2009;4:698-703.

[8] Sirianuntapiboon S, Jeeyachok N, Larplai R. Sequencing batch reactor biofilm system for treatment of milk industry wastewater. J Environ Manage 2005;76:177-183.

[9] Asadi A, Zinatizadeh AA, Hasnain Isa M. Performance of intermittently aerated up-flow sludge bed reactor and sequencing batch reactor treating industrial estate wastewater: A comparative study. Bioresour Technol 2012;123:495-506.

[10] Jianlong W, Hanchang S, Yi Q. Wastewater treatment in a hybrid biological reactor (HBR): effect of organic loading rates. Process Biochem 2000;36:297-303. 
[11] Zinadini S, Rahimi M, Zinatizadeh AA, Shaykhi Mehrabadi Z. High frequency ultrasound-induced sequence batch reactor as a practical solution for high rate wastewater treatment. J Environ Chem Eng $2015 ; 3: 217-226$

[12] Mason TJ, Cordemans ED. Ultrasonic intensification of chemical processing and related operations - A Review. Chem Eng Res Des 1996;74:511-516.

[13] Tiehm A, Nickel K, Zellhorn M, Neis U. Ultrasonic waste activated sludge disintegration for improving anaerobic stabilization. Water Res 2001;35:2003-2009.

[14] Ince NH, Tezcanli G, Belen RK, Apikyan İG. Ultrasound as a catalyzer of aqueous reaction systems: the state of the art and environmental applications. Appl Catal - B 2001;29:167-176.

[15] Wayment DG, Casadonte Jr DJ. Frequency effect on the sonochemical remediation of alachlor. Ultrason Sonochem 2002;9:251-257.

[16] Rezaee S, Zinatizadeh AA, Asadi A. High rate CNP removal from a milk processing wastewater in a single ultrasound augmented up-flow anaerobic/aerobic/anoxic bioreactor. Ultrason Sonochem 2015;23:289-301.

[17] Khuri AI, Cornell, JA. Response surfaces: design and analyses. New York: Marcel Dekker; 1996.

[18] American Public Health Association (APHA). Standard Methods for the Examination of Water and Wastewater. Washington: Amazon; 2005.

[19] Lateef A, Chaudhry MN, Ilyas S. Biological treatment of dairy wastewater using activated sludge. Sci Asia 2013;39:179-185.

[20] Amini M, Younesi H, Zinatizadeh Lorestani AA, Najafpour G. Determination of optimum conditions for dairy wastewater treatment in UAASB reactor for removal of nutrients. Bioresour Technol 2013;145:71-79.

[21] Mahvi AH. Sequencing batch reactor: a promising technology in wastewater treatment. Iran J Environ Health Sci Eng 2008;5:79-90.

[22] Fu Z, Yang F, An Y, Xue Y. Simultaneous nitrification and denitrification coupled with phosphorus removal in an modified anoxic/oxic-membrane bioreactor (A/O-MBR). Biochem Eng J 2009;43:191-196.

[23] Oh J, Silverstein J. Acetate limitation and nitrite accumulation during denitrification. J Environ Eng $1999 ; 125: 234-242$.

[24] Mansouri Y. Simultanouse High Rate Removal of Carbon and Nitrogen from Synthetic Wastewater in an Up-flow Aerobic/Anoxic Sludge Fixed Film Bioreactor. Razi University, Kermanshah, Iran 2010; Master thesis. [25] Xie B, Wang L, Liu H. Using low intensity ultrasound to improve the efficiency of biological phosphorus removal. Ultrason Sonochem 2008;15:775-781. 
[26] Pitt WG, Ross S. A. Ultrasound increases the rate of bacterial cell growth. Biotechnol Progr 2003;19(3):1038-1044.

[27] Coats ER, Mockos A, Loge FJ. Post-anoxic denitrification driven by PHA and glycogen within enhanced biological phosphorus removal. Bioresour Technol 2011;102:1019-1027.

[28] Bamforth SM, Singleton I. Bioremediation of polycyclic aromatic hydrocarbons: current knowledge and future directions. J Chem Technol Biotechnol 2005;80:723-736.

[29] Xie B, Liu H. Enhancement of biological nitrogen removal from wastewater by low-intensity ultrasound. Water Air Soil Pollut 2010;211:157-163.

[30] Broughton A, Pratt S, Shilton A. Enhanced biological phosphorus removal for high-strength wastewater with a low rbCOD:P ratio. Bioresour Technol 2008;99:1236-1241.

[31] Liu Y, Takatsuki H, Yoshikoshi A, Wang B, Sakanishi A. Effects of ultrasound on the growth and vacuolar H+-ATPase activity of aloe arborescens callus cells. Colloids Surf 2003;32:105-116.

[32] Wu LLJ. Enhancement of shikonin production in singleand two-phase suspension cultures of Lithospermum erythrorhizon cells using low-energy ultrasound. Biotechnol Bioeng 2002;78(1):81-88.

[33] Komarov SV, Kuwabara M, Abramov OV. High Power Ultrasonics in Pyrometallurgy: Current Status and Recent Development. ISIJ Int 2005;45:1765-1782.

[34] Wunsch WH, Neis U. Combatting bulking sludge with ultrasound. TU Hamburg-Harburg Reports on Sanitary Eng 2002;35:201-212.

[35] Zhang G, Zhang P, Chen Y. Ultrasonic enhancement of industrial sludge settling ability and dewatering ability. Tsinghua Sci Technol 2006;11:374-378.

[36] Parvizian F, Rahimi M, Hosseini SM, Madaeni SS, Alsairafi AA. The effect of high frequency ultrasound on diffusion boundary layer resistance in ion-exchange membrane transport. Desalination 2012;286:155-165.

[37] Gondrexon N, Renaudin V, Petrier C, Clement M, Boldo P, Gonthier Y, Bernis A. Experimental study of the hydrodynamic behaviour of a high frequency ultrasonic reactor. Ultrason Sonochem 1998;5:1-6.

[38] Metcalf E. Wastewater engineering treatment and reuse. 4th ed. New York: McGraw-Hill; 2003.

[39] Chen T-C, Shen Y-H, Lee W-J, Lin C-C, Wan M-W. An economic analysis of the continuous ultrasoundassisted oxidative desulfurization process applied to oil recovered from waste tires. J Cleaner Prod 2013;39:129136.

[40] Tsai WT, Chou YH. Government policies for encouraging industrial waste reuse and pollution prevention in Taiwan. J Cleaner Prod 2004;12:725-736. 


\begin{tabular}{|c|c|}
\hline Figure No. & Figure caption \\
\hline 1 & Schematic diagram of the experimental setup. \\
\hline 2 & $\begin{array}{l}\text { sCOD removal as a function of MLSS and HRT at different aeration modes in the (a) } \\
\text { ultrasound-mixed UAAASB, and (b) UAAASB with mechanical mixing. }\end{array}$ \\
\hline 3 & $\begin{array}{l}\text { Response surface plot for TN removal efficiency as a function of MLSS and HRT at } \\
\text { different aeration modes in the (a) ultrasound-mixed UAAASB, and (b) UAAASB with } \\
\text { mechanical mixing. }\end{array}$ \\
\hline 4 & $\begin{array}{l}\text { Nitrogen fractionation in the influent and effluent under different operating conditions } \\
\text { applied in the (a) ultrasound-mixed UAAASB, and (b) UAAASB with mechanical mixing. }\end{array}$ \\
\hline 5 & $\begin{array}{l}\text { Response surface plot for TP removal efficiency as a function of MLSS and aeration mode } \\
\text { at different HRTs in the (a) ultrasound-mixed UAAASB, and (b) UAAASB with } \\
\text { mechanical mixing. }\end{array}$ \\
\hline 6 & $\begin{array}{l}\text { Response surface plots for SVI as a function of MLSS and HRT at different aeration } \\
\text { modes in the (a) ultrasound-mixed UAAASB, and (b) UAAASB with mechanical mixing. }\end{array}$ \\
\hline 7 & Height of sludge under different operating conditions. \\
\hline 8 & $\begin{array}{l}\text { Overlay plot for the optimal region as a function of MLSS and HRT at different aeration } \\
\text { modes for the (a) ultrasound-mixed UAAASB, and (b) UAAASB with mechanical mixing. }\end{array}$ \\
\hline
\end{tabular}




\begin{tabular}{|c|l|}
\hline Table No. & Table caption \\
\hline 1 & Characteristics of Sahra's dairy industrial wastewater. \\
\hline 2 & Experimental range and levels of the independent variables. \\
\hline 3 & Experimental conditions and results for the ultrasound-augmented UAAASB bioreactor. \\
\hline 4 & Experimental conditions and results for the UAAASB bioreactor with mechanical mixing. \\
\hline 5 & ANOVA results for the equations of the Design Expert 7.0 for studied responses. \\
\hline 6 & The optimization criteria for the responses studied. \\
\hline 7 & Verification experiments at optimum conditions for ultrasound-augmented UAAASB. \\
\hline 8 & \\
\hline
\end{tabular}




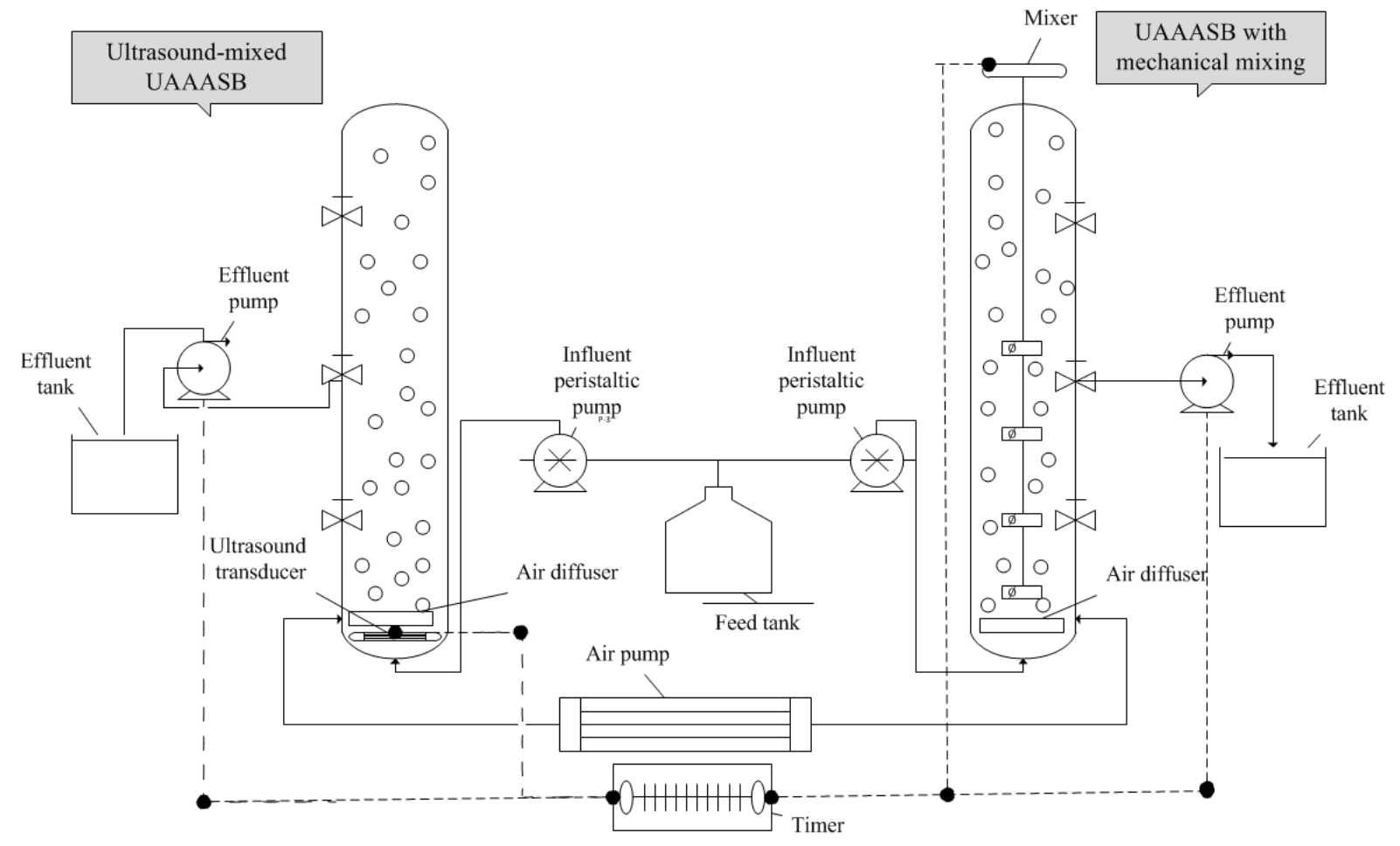

Figure 1. Schematic diagram of the experimental setup. 


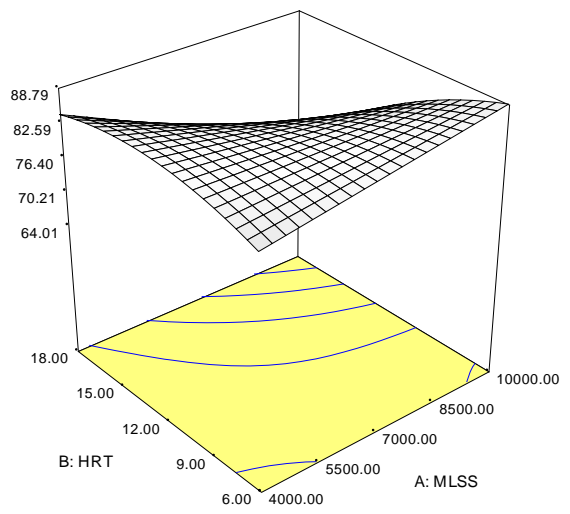

Aeration mode: 1

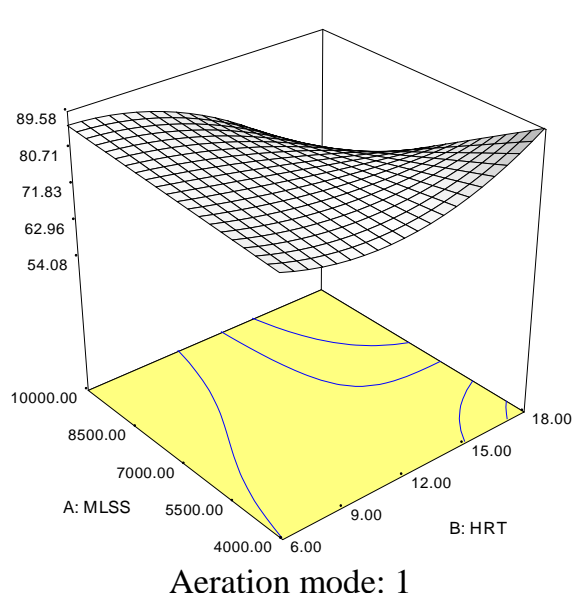

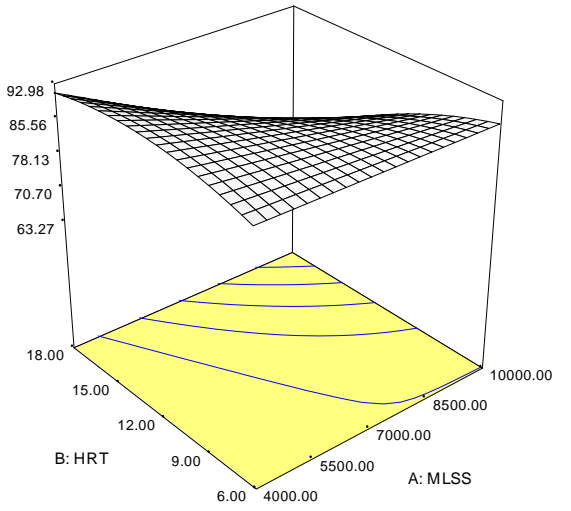

Aeration mode: 1.5

(a)

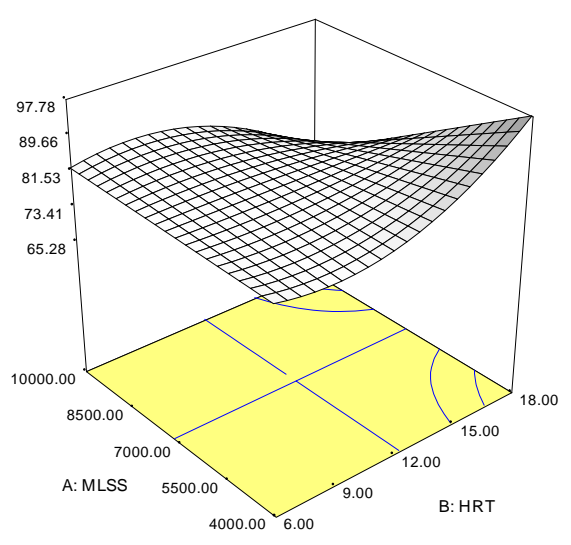

Aeration mode: 1.5

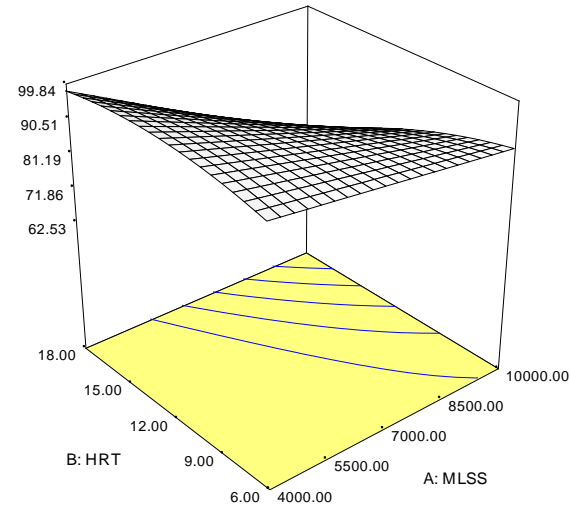

Aeration mode: 2

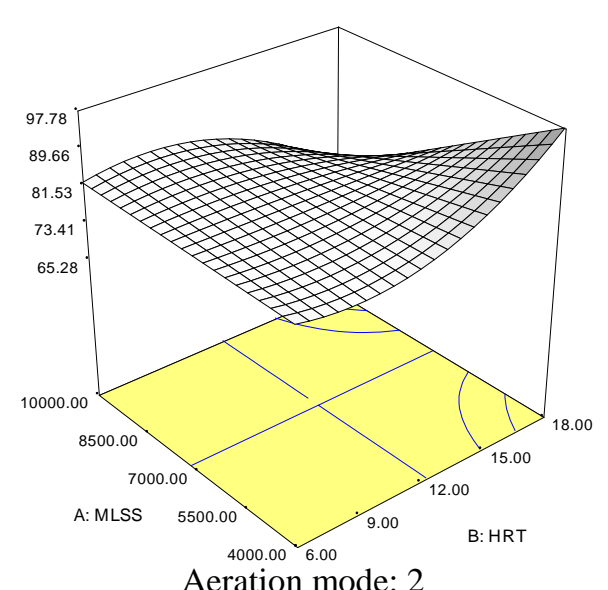

Aeration mode: 2

(b)

Figures 2. sCOD removal as a function of MLSS and HRT at different aeration modes in the (a) ultrasound-mixed UAAASB, and (b) UAAASB with mechanical mixing. 


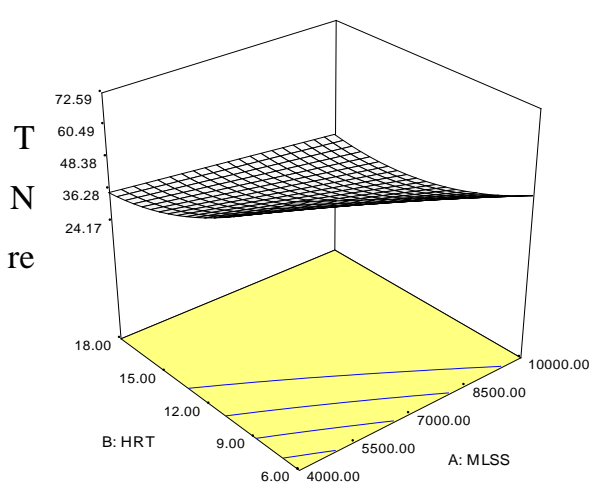

Aeration mode: 1

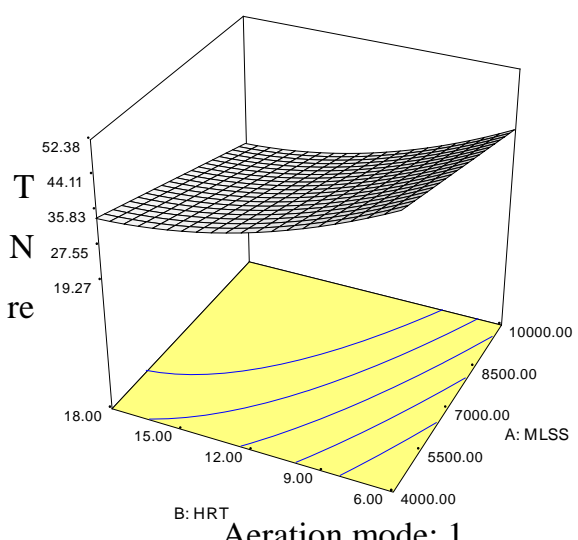

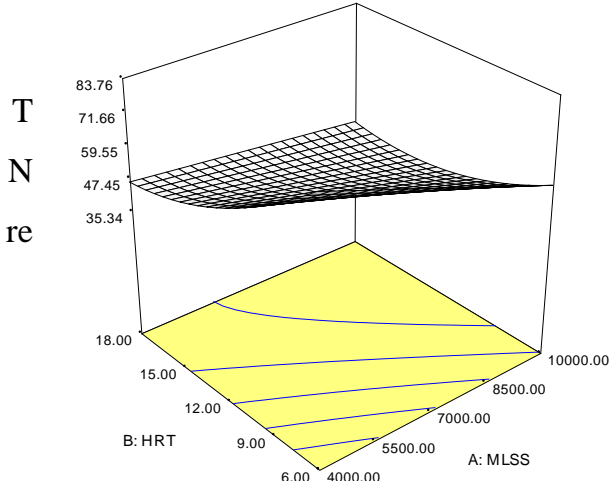

Aeration mode: 1.5

(a)

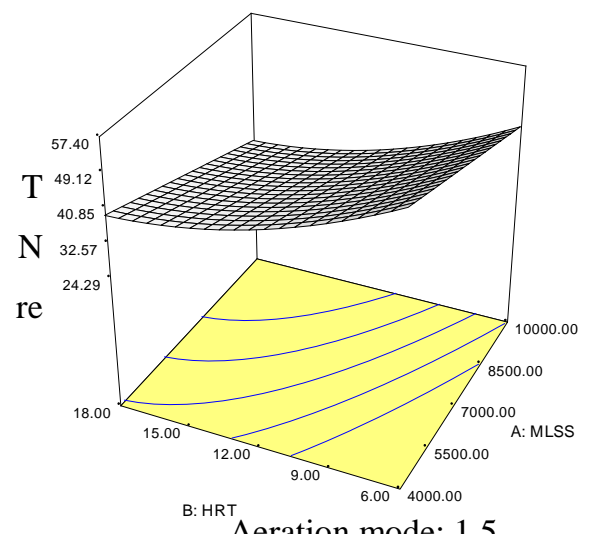

Aeration mode: 1.5

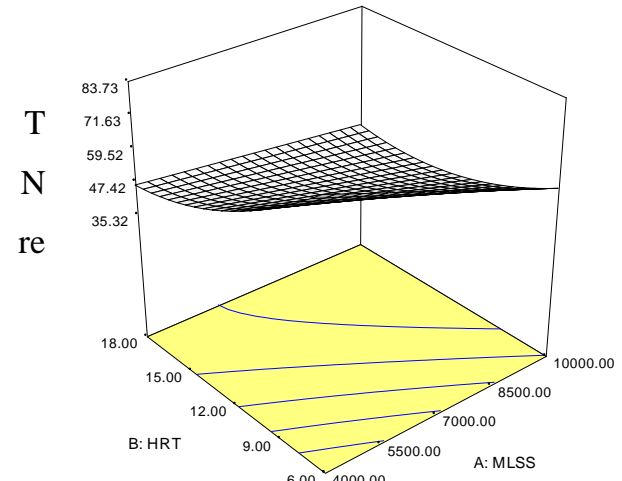

Aeration mode: 2

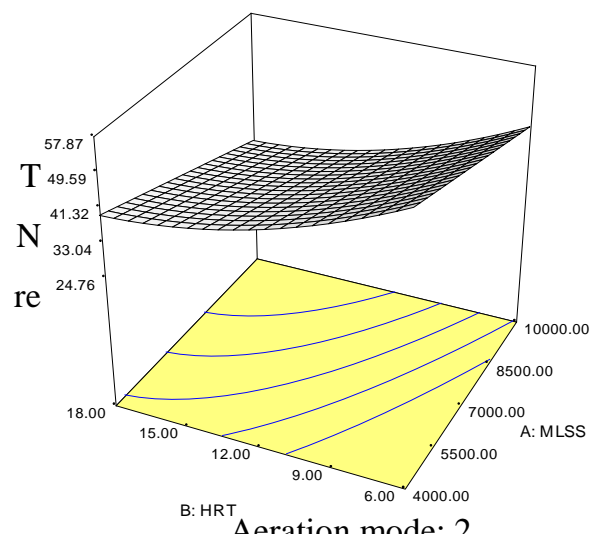

Aeration mode: 2

Figure 3. Response surface plot for TN removal efficiency as a function of MLSS and HRT at different aeration modes in the (a) ultrasound-mixed UAAASB, and (b) UAAASB with mechanical mixing. 


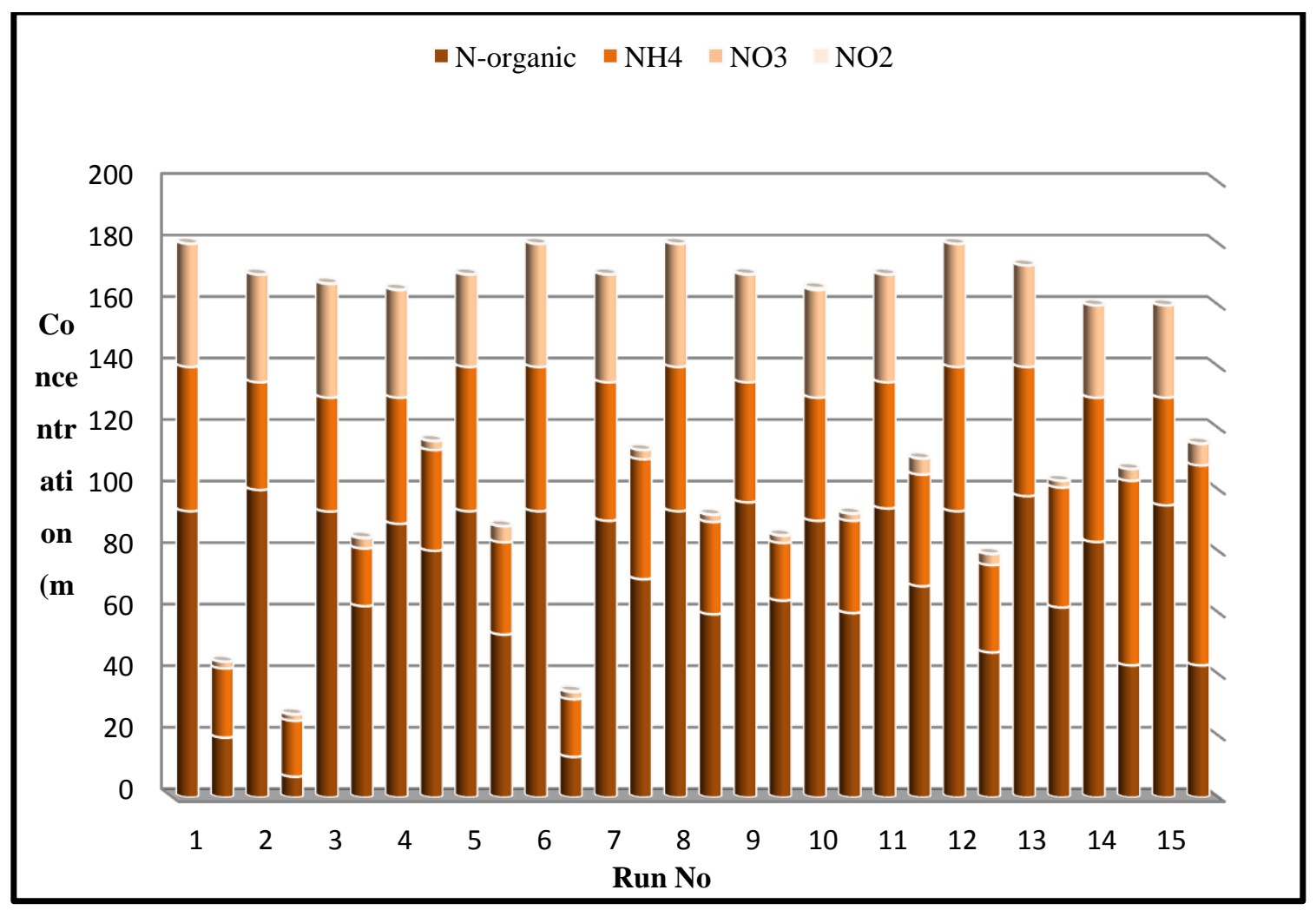

(a)

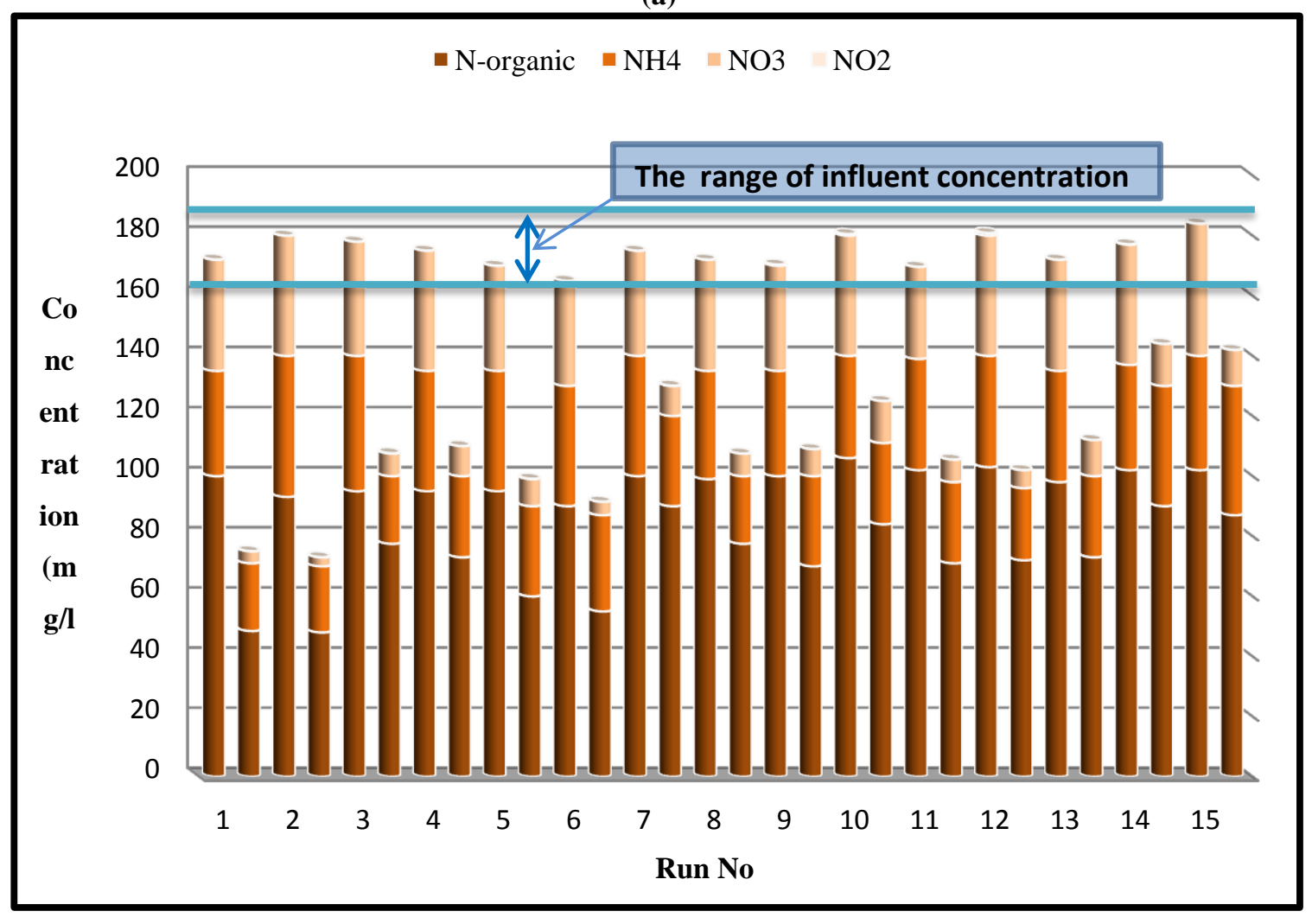

(b)

Figure 4. Nitrogen fractionation in the influent and effluent under different operating conditions applied in the (a) ultrasound-mixed UAAASB, and (b) UAAASB with mechanical mixing. 

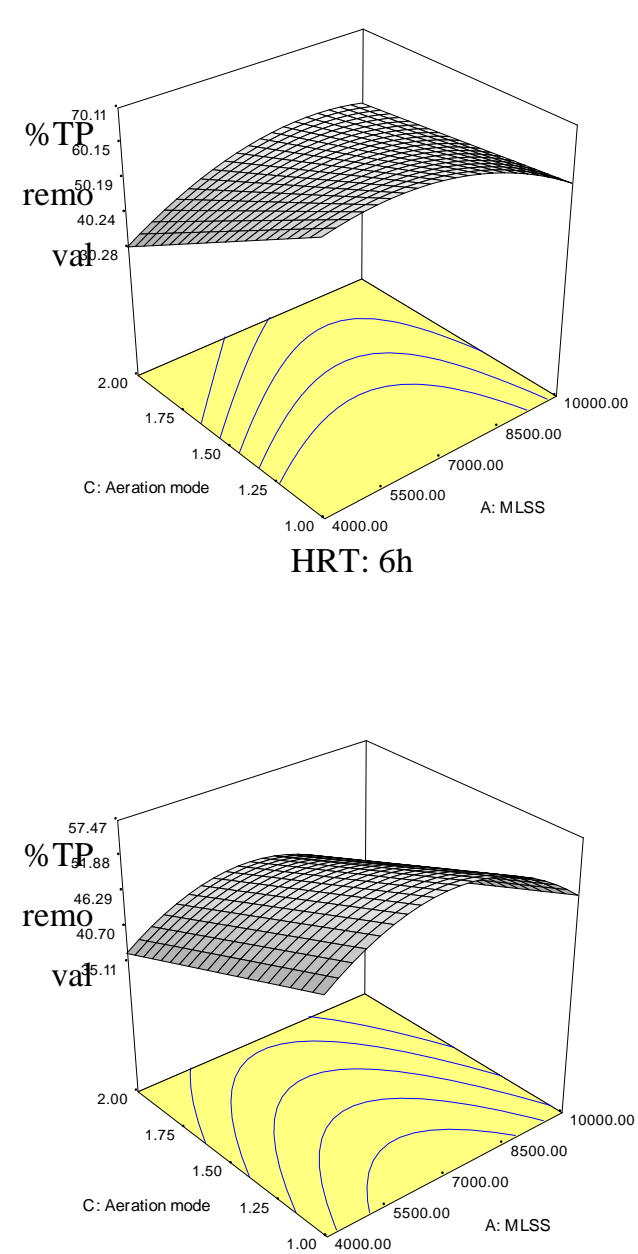

HRT: $6 \mathrm{~h}$

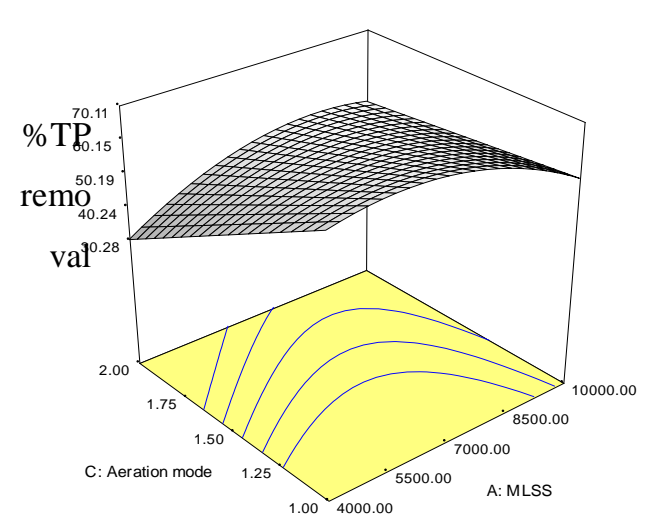

HRT: $12 \mathrm{~h}$

(A)

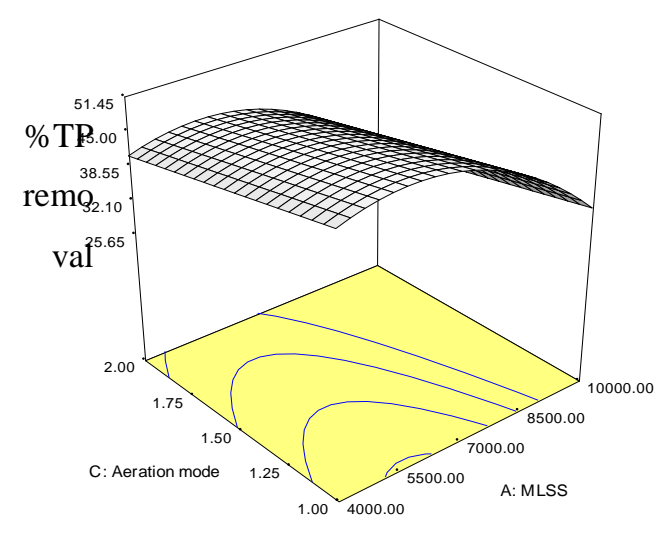

HRT: $12 \mathrm{~h}$

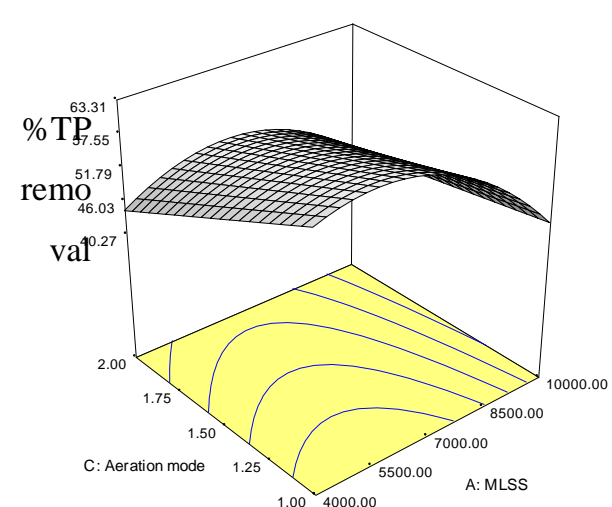

HRT: $18 \mathrm{~h}$

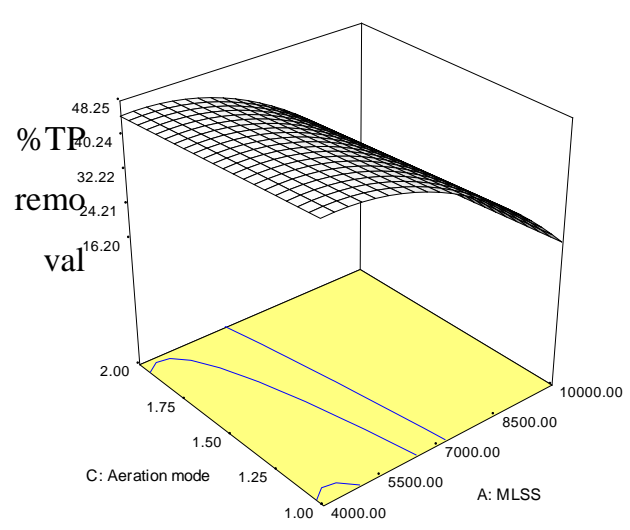

HRT: $18 \mathrm{~h}$

(B)

Figure 5. Response surface plot for TP removal efficiency as a function of MLSS and aeration mode at different HRTs in the (a) ultrasound-mixed UAAASB, and (b) UAAASB with mechanical mixing. 


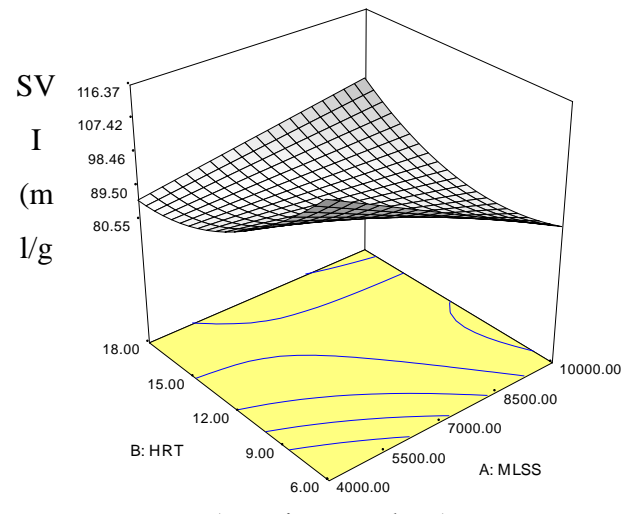

Aeration mode: 1

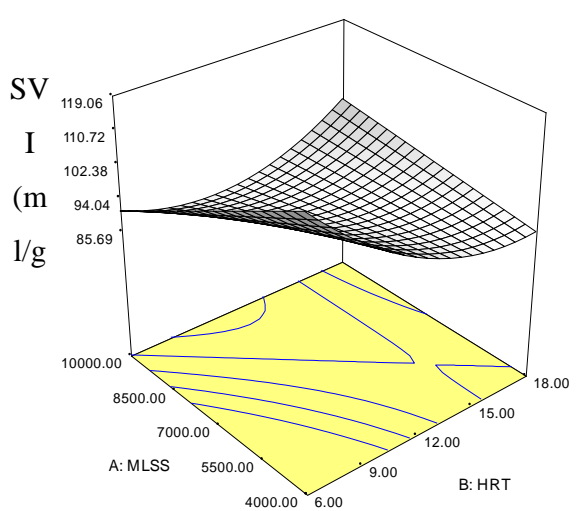

Aeration mode: 1

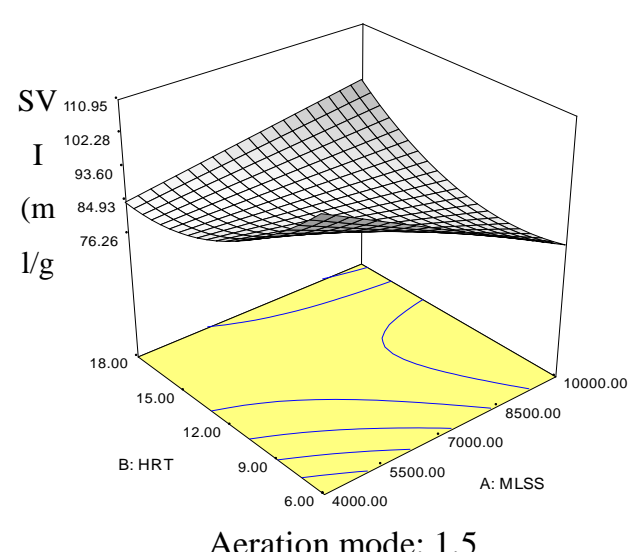

Aeration mode: 1.5

(a)

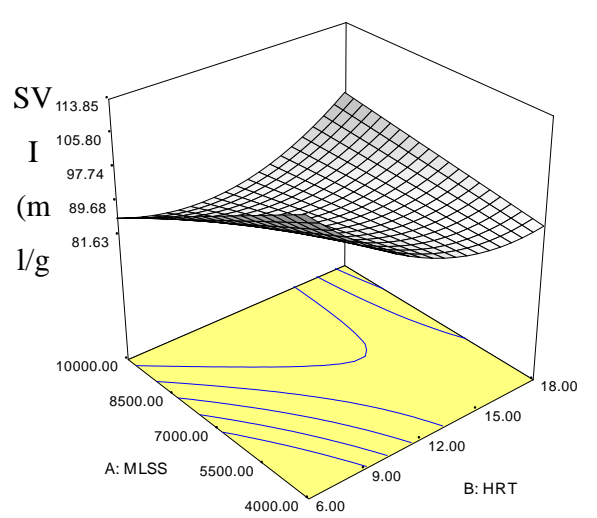

Aeration mode: 1.5

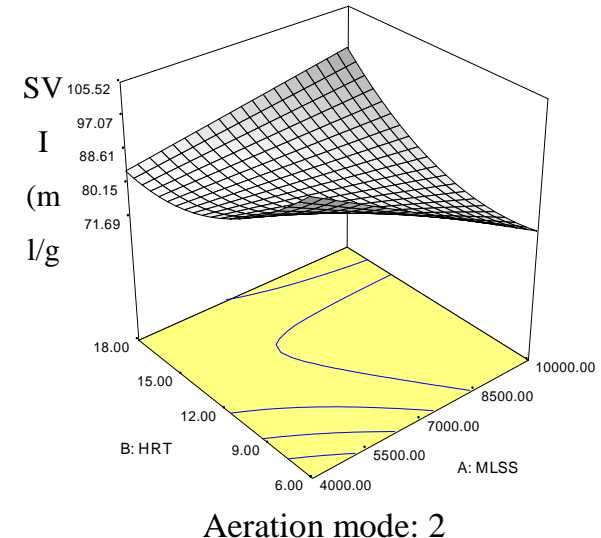

Aeration mode: 2

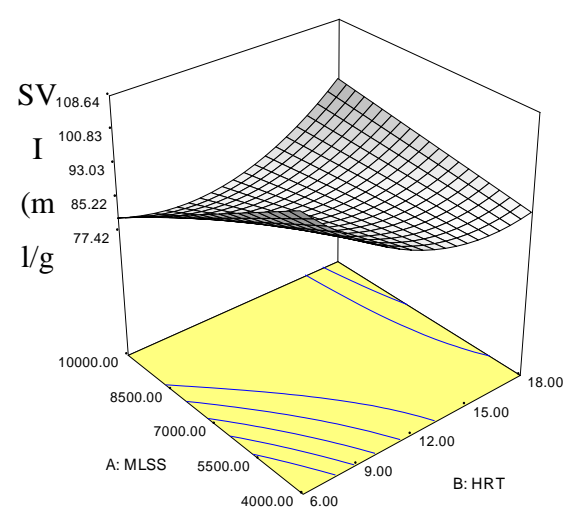

Aeration mode: 2

Figure 6. Response surface plots for SVI as a function of MLSS and HRT at different aeration modes in the (a) ultrasound-mixed UAAASB, and (b) UAAASB with mechanical mixing. 


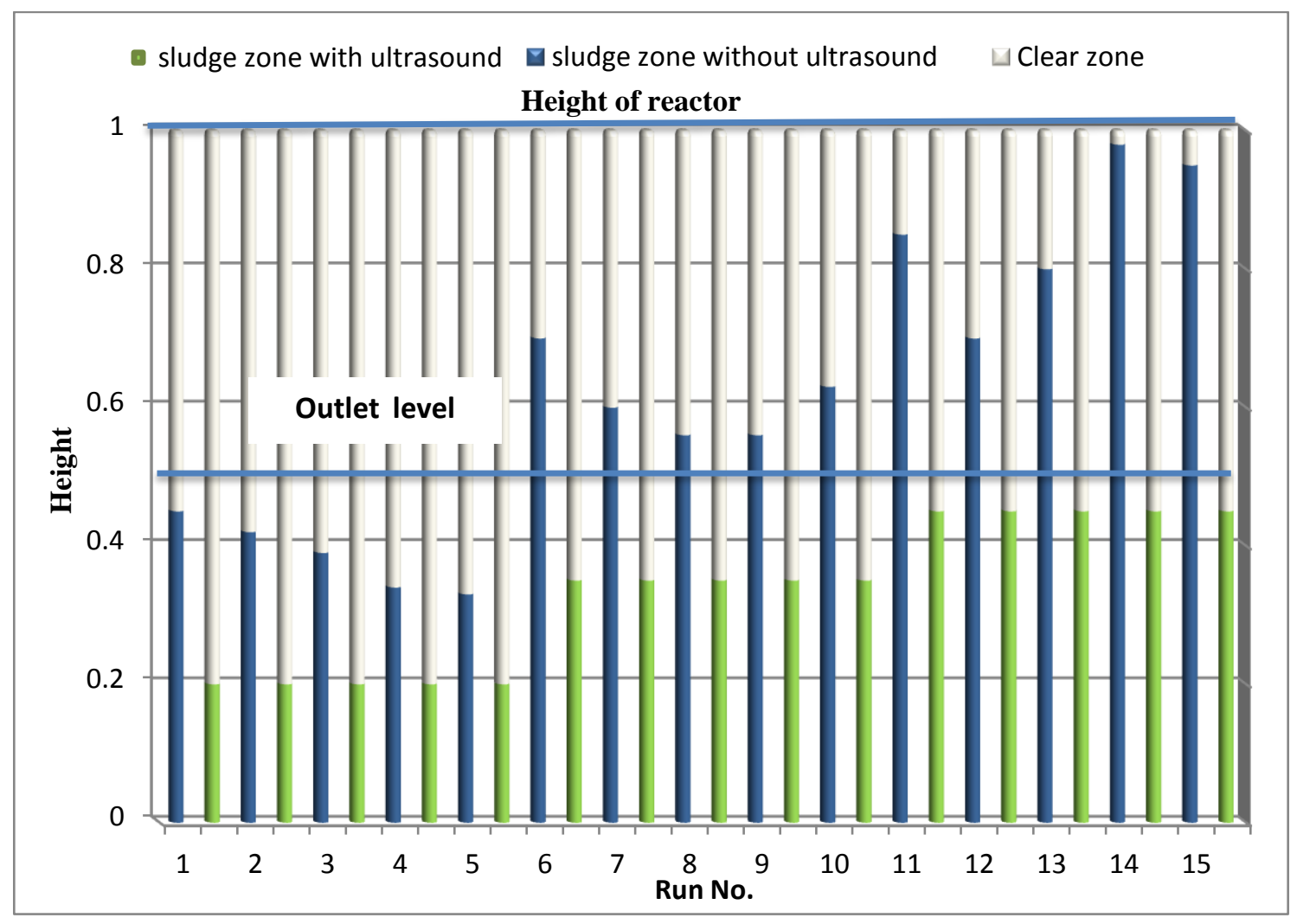

Figure 7. Height of sludge under different operating conditions. 


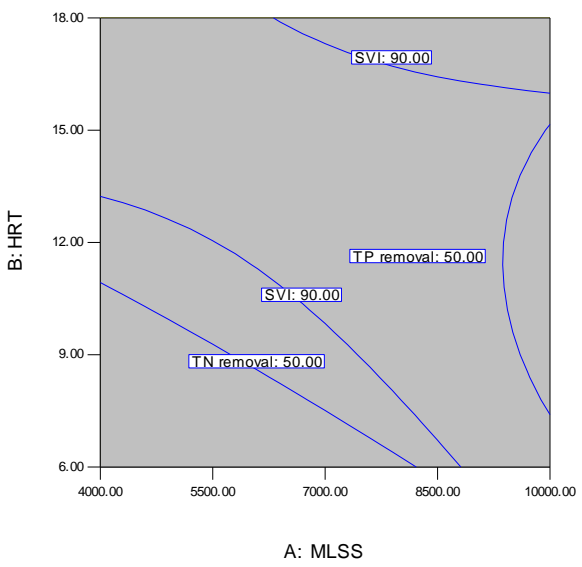

Aeration mode: 1

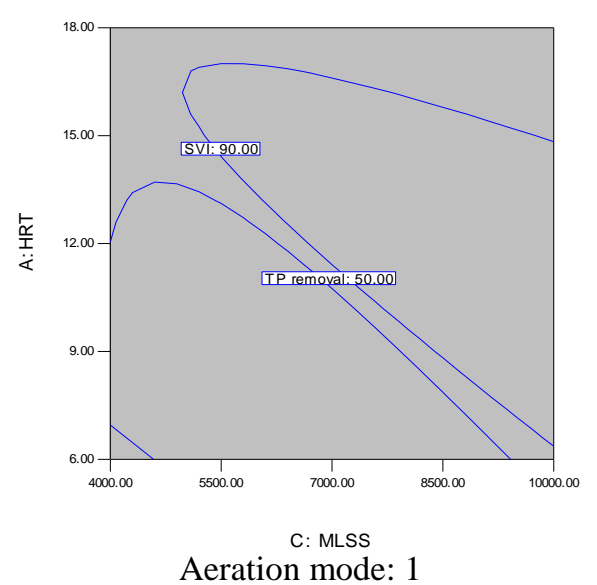

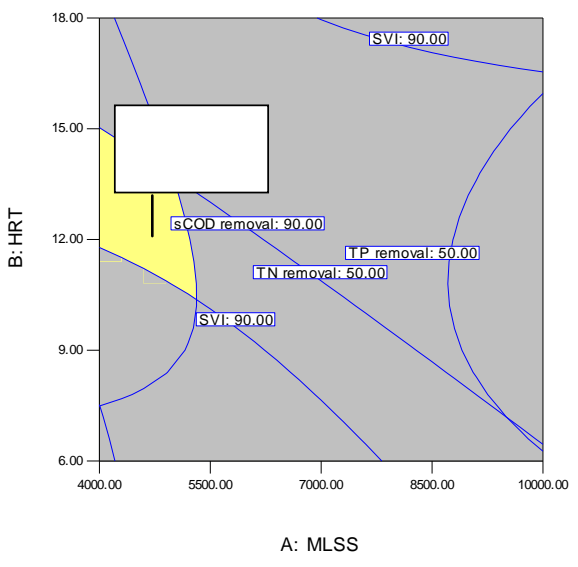

Aeration mode: 1.5

(a)

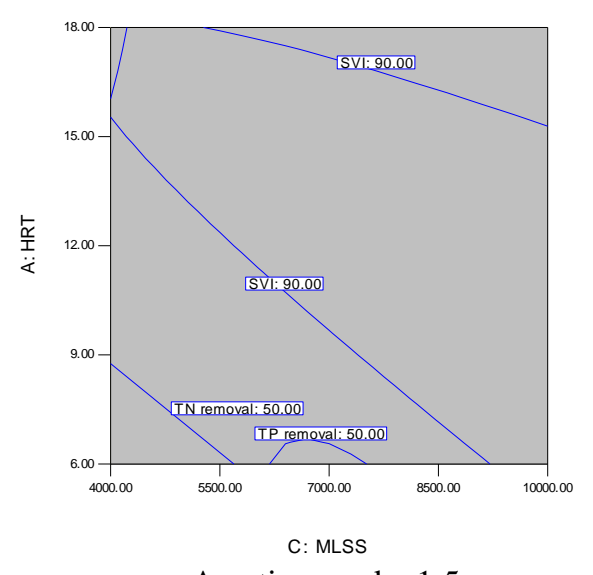

Aeration mode: 1.5

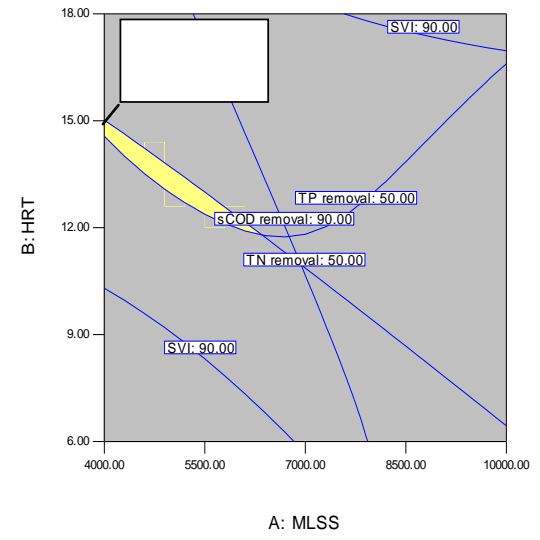

Aeration mode: 2

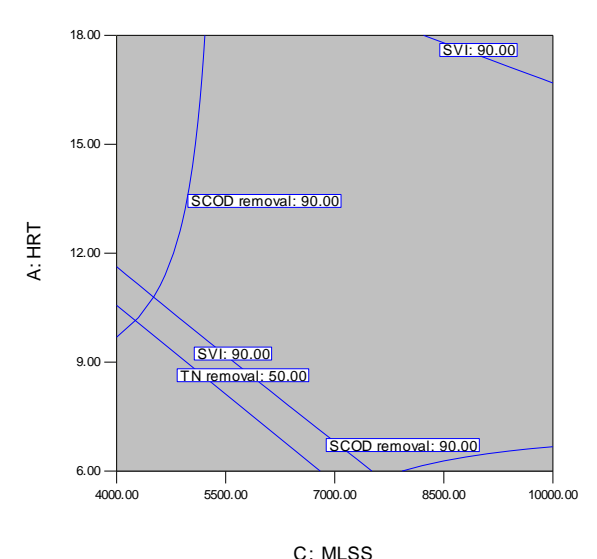

Aeration mode: 2

(b)

Figure 8. Overlay plot for the optimal region as a function of MLSS and HRT at different aeration modes for the (a) ultrasound-mixed UAAASB, and (b) UAAASB with mechanical mixing. 
Table 1. Characteristics of Sahra's dairy industrial wastewater.

\begin{tabular}{|c|c|c|}
\hline Parameters & Unit & Amount \\
\hline sCOD & $(\mathrm{mg} / \mathrm{l})$ & $900-1200$ \\
\hline $\mathrm{BOD}_{5}$ & $(\mathrm{mg} / \mathrm{l})$ & $640-850$ \\
\hline TN & $(\mathrm{mg} / \mathrm{l})$ & $160-180$ \\
\hline $\mathrm{TP}$ & $(\mathrm{mg} / \mathrm{l})$ & $48-52$ \\
\hline TSS & $(\mathrm{mg} / \mathrm{l})$ & $40-50$ \\
\hline $\mathrm{pH}$ & - & $6.8-7.2$ \\
\hline
\end{tabular}

Table 2. Experimental range and levels of the independent variables.

\begin{tabular}{lccc}
\hline & \multicolumn{3}{c}{ Range and levels } \\
\hline Variables & -1 & 0 & +1 \\
\hline HRT, h & 6 & 12 & 18 \\
MLSS, mg/l & 4000 & 7000 & 10000 \\
Aeration mode & 1 & 1.5 & 2 \\
\hline
\end{tabular}


Table 3. Experimental conditions and results for the ultrasound-augmented UAAASB bioreactor.

\begin{tabular}{|c|c|c|c|c|c|c|c|c|c|c|c|c|c|c|c|}
\hline \multirow[b]{2}{*}{ Run } & \multicolumn{3}{|c|}{ Variables } & \multicolumn{12}{|c|}{ Responses } \\
\hline & $\begin{array}{c}\text { Factor1 } \\
\text { A:HRT, } \\
\text { (h) }\end{array}$ & $\begin{array}{c}\text { Factor2 } \\
\text { B:MLSS, } \\
(\mathrm{mg} / \mathrm{l})\end{array}$ & $\begin{array}{c}\text { Factor3 } \\
\text { C: } \\
\text { Aeration } \\
\text { mode }\end{array}$ & F/M & $\begin{array}{c}\text { SCOD } \\
\text { removal, } \\
(\%)\end{array}$ & $\begin{array}{c}\text { TN } \\
\text { removal, } \\
(\%)\end{array}$ & $\begin{array}{c}\text { TKN } \\
\text { removal, } \\
(\%)\end{array}$ & $\begin{array}{l}\text { Effluent } \\
\text { N-NO3, } \\
\text { (mg/l) }\end{array}$ & $\begin{array}{l}\text { Effluent } \\
\text { N-NO2, } \\
\text { (mg/l) }\end{array}$ & $\begin{array}{l}\text { Denitrification } \\
\text { rate, } \\
\text { (g/l.d) }\end{array}$ & $\begin{array}{c}\mathrm{TP} \\
\text { removal, } \\
(\%)\end{array}$ & $\begin{array}{l}\text { Effluent } \\
\text { Turbidity, } \\
\text { (NTU) }\end{array}$ & $\begin{array}{l}\text { SVI, } \\
(\mathrm{ml} / \mathrm{g})\end{array}$ & $\begin{array}{l}\text { Height of } \\
\text { sludge, } \\
\text { (m) }\end{array}$ & $\begin{array}{c}\text { DO, } \\
(\mathrm{mg} / \mathrm{l})\end{array}$ \\
\hline 1 & 6 & 4000 & 1 & 1 & 84.66 & 75.43 & 70 & 2.19 & 0.05 & 0.381 & 68.94 & 16 & 112.5 & 0.25 & 4.2 \\
\hline 2 & 6 & 4000 & 2 & 1 & 93.11 & 84.01 & 81.48 & 2 & 0.19 & 0.388 & 30.68 & 12 & 105 & 0.25 & 4.1 \\
\hline 3 & 12 & 4000 & 1.5 & 0.5 & 96.75 & 53.01 & 37.69 & 3.33 & 0.148 & 0.031 & 52 & 2 & 97.5 & 0.25 & 4.1 \\
\hline 4 & 18 & 4000 & 1 & 0.33 & 83 & 29.75 & 13.07 & 2.91 & 0.1068 & 0.025 & 54 & 8 & 85 & 0.25 & 4 \\
\hline 5 & 18 & 4000 & 2 & 0.33 & 98.1 & 48 & 40.17 & 5.21 & 0.1031 & 0.066 & 56.16 & 3 & 82.5 & 0.25 & 4 \\
\hline 6 & 6 & 7000 & 1.5 & 0.57 & 86.35 & 65.42 & 77.14 & 2.36 & 0.23 & 0.355 & 53 & 9 & 100 & 0.35 & 3.8 \\
\hline 7 & 12 & 7000 & 1 & 0.28 & 81.83 & 33.57 & 18.51 & 7 & 0.030 & 0.044 & 60 & 8 & 85 & 0.35 & 3.7 \\
\hline 8 & 12 & 7000 & 1.5 & 0.28 & 81.6 & 48.99 & 36 & 2.36 & 0.137 & 0.112 & 60.16 & 5 & 80 & 0.35 & 3.9 \\
\hline 9 & 12 & 7000 & 2 & 0.28 & 95.91 & 50 & 38.66 & 2.36 & 0.114 & 0.050 & 53.2 & 2 & 80 & 0.35 & 3.8 \\
\hline 10 & 18 & 7000 & 1.5 & 0.19 & 80 & 44.20 & 30.76 & 2.3 & 0.122 & 0.058 & 67.6 & 6 & 90 & 0.35 & 3.9 \\
\hline 11 & 6 & 10000 & 1 & 0.4 & 86.97 & 35.14 & 22.22 & 11.6 & 0.126 & 0.090 & 56 & 9 & 85 & 0.45 & 2.9 \\
\hline 12 & 6 & 10000 & 2 & 0.4 & 89.91 & 55.95 & 46 & 11.8 & 0.095 & 0.266 & 48.52 & 7 & 70 & 0.45 & 2.8 \\
\hline 13 & 12 & 10000 & 1.5 & 0.2 & 85.73 & 40.44 & 28 & 2.21 & 0.044 & 0.069 & 42 & 7 & 80 & 0.45 & 2.9 \\
\hline 14 & 18 & 10000 & 1 & 0.13 & 67.11 & 33.23 & 20.76 & 3.82 & 0.030 & 0.042 & 58.94 & 5 & 98 & 0.45 & 2.8 \\
\hline 15 & 18 & 10000 & 2 & 0.13 & 57.24 & 28.04 & 16.92 & 9.8 & 0.157 & 0.035 & 46 & 3 & 95 & 0.45 & 2.8 \\
\hline 16 & 12 & 7000 & 1.5 & 0.28 & 82.45 & 45.77 & 33.78 & 2.78 & 0.133 & 0.108 & 55.75 & 5 & 82 & 0.35 & 3.8 \\
\hline 17 & 12 & 7000 & 1.5 & 0.28 & 80.63 & 46.96 & 32.17 & 3.69 & 0.115 & 0.111 & 58.36 & 4 & 80 & 0.35 & 3.7 \\
\hline 18 & 12 & 7000 & 1.5 & 0.28 & 85.54 & 44.12 & 37.86 & 2.14 & 0.125 & 0.107 & 61.89 & 5 & 79 & 0.35 & 3.4 \\
\hline 19 & 12 & 7000 & 1.5 & 0.28 & 75.89 & 50.36 & 40.89 & 1.65 & 0.033 & 0.098 & 65.42 & 3 & 75 & 0.35 & 3.5 \\
\hline 20 & 12 & 7000 & 1.5 & 0.28 & 79.41 & 41.36 & 35.48 & 3.25 & 0.145 & 0.088 & 63.47 & 6 & 75 & 0.35 & 3.9 \\
\hline
\end{tabular}


Table 4. Experimental conditions and results for the UAAASB bioreactor with mechanical mixing.

\begin{tabular}{|c|c|c|c|c|c|c|c|c|c|c|c|c|c|c|c|}
\hline \multirow[b]{2}{*}{ Run } & \multicolumn{3}{|c|}{ Variables } & \multicolumn{12}{|c|}{ Responses } \\
\hline & $\begin{array}{c}\text { Factor 1 } \\
\text { A:HRT, } \\
\text { (h) }\end{array}$ & $\begin{array}{c}\text { Factor 2 } \\
\text { B:MLSS, } \\
(\mathrm{mg} / \mathrm{l})\end{array}$ & $\begin{array}{c}\text { Factor } 3 \\
\text { C: } \\
\text { Aeration } \\
\text { mode }\end{array}$ & $\mathrm{F} / \mathrm{M}$ & $\begin{array}{c}\text { SCOD } \\
\text { removal, } \\
(\%)\end{array}$ & $\begin{array}{c}\text { TN } \\
\text { removal, } \\
(\%)\end{array}$ & $\begin{array}{c}\text { TKN } \\
\text { removal, } \\
(\%)\end{array}$ & $\begin{array}{l}\text { Effluent } \\
\text { N-NO3, } \\
\text { (mg/l) }\end{array}$ & $\begin{array}{l}\text { Effluent } \\
\text { N-NO2, } \\
\text { (mg/l) }\end{array}$ & $\begin{array}{c}\text { Denitrification } \\
\text { rate, } \\
\text { (g/l.d) }\end{array}$ & $\begin{array}{c}\text { TP } \\
\text { removal, } \\
(\%)\end{array}$ & $\begin{array}{l}\text { Effluent } \\
\text { Turbidity, } \\
\text { (NTU) }\end{array}$ & $\begin{array}{l}\text { SVI, } \\
(\mathrm{ml} / \mathrm{g})\end{array}$ & $\begin{array}{l}\text { Height of } \\
\text { sludge, } \\
\text { (m) }\end{array}$ & $\begin{array}{c}\text { DO, } \\
(\mathrm{mg} / \mathrm{l})\end{array}$ \\
\hline 1 & 6 & 4000 & 1 & 1 & 82 & 56 & 46 & 4 & 0.03 & 0.220 & 50 & 21 & 117.5 & 0.47 & 4.1 \\
\hline 2 & 6 & 4000 & 2 & 1 & 90 & 59 & 51 & 3 & 0.028 & 0.230 & 54 & 18 & 107 & 0.43 & 4.2 \\
\hline 3 & 12 & 4000 & 1.5 & 0.5 & 86 & 39 & 28.57 & 4.5 & 0.013 & 0.075 & 48 & 12 & 100 & 0.40 & 4.1 \\
\hline 4 & 18 & 4000 & 1 & 0.33 & 88 & 37 & 26 & 10 & 0.028 & 0.053 & 25 & 14 & 90 & 0.36 & 4 \\
\hline 5 & 18 & 4000 & 2 & 0.33 & 94 & 41 & 33.33 & 9 & 0.013 & 0.063 & 48 & 10 & 85 & 0.34 & 4 \\
\hline 6 & 6 & 7000 & 1.5 & 0.57 & 88 & 44.48 & 33 & 4.5 & 0.010 & 0.126 & 45 & 19 & 104.2 & 0.73 & 3.7 \\
\hline 7 & 12 & 7000 & 1 & 0.28 & 76 & 25.66 & 14.28 & 10 & 0.102 & 0.051 & 50 & 13 & 93 & 0.65 & 3.7 \\
\hline 8 & 12 & 7000 & 1.5 & 0.28 & 81.6 & 37.5 & 26 & 7.5 & 0.040 & 0.087 & 44 & 11 & 86 & 0.60 & 3.6 \\
\hline 9 & 12 & 7000 & 2 & 0.28 & 87 & 36.01 & 26 & 9 & 0.025 & 0.056 & 40.96 & 10 & 86 & 0.60 & 3.5 \\
\hline 10 & 18 & 7000 & 1.5 & 0.19 & 80.6 & 30.75 & 20.71 & 14 & 0.035 & 0.018 & 40 & 14 & 93 & 0.63 & 3.7 \\
\hline 11 & 6 & 10000 & 1 & 0.4 & 86.9 & 37.65 & 29.5 & 7.5 & 0.024 & 0.150 & 45.48 & 19 & 90 & 0.90 & 2.9 \\
\hline 12 & 6 & 10000 & 2 & 0.4 & 95 & 43.6 & 31.42 & 6 & 0.020 & 0.180 & 40.08 & 12 & 80 & 0.80 & 2.8 \\
\hline 13 & 12 & 10000 & 1.5 & 0.2 & 86 & 34.87 & 26 & 12 & 0.041 & 0.056 & 30 & 7 & 80 & 0.80 & 2.9 \\
\hline 14 & 18 & 10000 & 1 & 0.13 & 68 & 18.69 & 5.1 & 14 & 0.030 & 0.001 & 20 & 8 & 98 & 0.98 & 2.8 \\
\hline 15 & 18 & 10000 & 2 & 0.13 & 78 & 22.83 & 7.14 & 12 & 0.035 & 0.011 & 14 & 7 & 95 & 0.95 & 2.8 \\
\hline 16 & 12 & 7000 & 1.5 & 0.28 & 81 & 37.5 & 26 & 7.5 & 0.04 & 0.050 & 48 & 11 & 86 & 0.60 & 3.7 \\
\hline 17 & 12 & 7000 & 1.5 & 0.28 & 79 & 39 & 29 & 6 & 0.03 & 0.080 & 52 & 8 & 82 & 0.57 & 3.4 \\
\hline 18 & 12 & 7000 & 1.5 & 0.28 & 85 & 42 & 31 & 7 & 0.028 & 0.070 & 50 & 10 & 88 & 0.62 & 3.5 \\
\hline 19 & 12 & 7000 & 1.5 & 0.28 & 83 & 35 & 22 & 5.5 & 0.04 & 0.070 & 46 & 12 & 84 & 0.58 & 3.7 \\
\hline 20 & 12 & 7000 & 1.5 & 0.28 & 76 & 36 & 26 & 7.5 & 0.04 & 0.061 & 47 & 7 & 85 & 0.59 & 3.4 \\
\hline
\end{tabular}


Table 5. Aeration strategy at the different aeration conditions.

\begin{tabular}{ccc}
\hline Aeration mode & Aeration (min) & Non aeration (min) \\
\hline 1 & 90 & 90 \\
1.5 & 108 & 72 \\
2 & 120 & 60 \\
\hline
\end{tabular}

Table 6. ANOVA results for the equations of the Design Expert 7.0 for studied responses

\begin{tabular}{|c|c|c|c|c|c|c|c|c|c|c|}
\hline Type of reactor & Response & Modified Equations with significant terms & Probability & $\mathbf{R}^{2}$ & $\operatorname{Adj} . \mathbf{R}^{2}$ & $\begin{array}{l}\text { Adeq. } \\
\text { precision }\end{array}$ & S.D & $\mathbf{C V}$ & PRESS & $\begin{array}{l}\text { Probability } \\
\text { for lack of fit }\end{array}$ \\
\hline \multirow{4}{*}{$\begin{array}{l}\text { Ultrasound-augmented } \\
\text { UAAASB }\end{array}$} & sCOD removal & $+85.87-6.97 \mathrm{~A}-5.53 \mathrm{~B}+3.06 \mathrm{C}-3.24 \mathrm{~B}^{2}-6.86 \mathrm{AB}-3.80 \mathrm{AC}$ & 0.0002 & 0.8301 & 0.7517 & 12.565 & 4.74 & 5.63 & 838.30 & 0.1812 \\
\hline & $\mathrm{TN}$ removal & $+47.31-10.27 \mathrm{~A}-12.94 \mathrm{~B}+5.57 \mathrm{C}+7.43 \mathrm{~B}^{2}-5.60 \mathrm{C}^{2}+5.82 \mathrm{AB}$ & $<0.0001$ & 0.8965 & 0.8487 & 17.469 & 5.57 & 11.55 & 1177.19 & 0.5734 \\
\hline & TP removal & $\begin{array}{l}+55.79-5.00 \mathrm{~A}+3.36 \mathrm{~B}-5.53 \mathrm{C}-7.94 \mathrm{~A}^{2}+5.36 \mathrm{~B}^{2}+2.96 \\
\mathrm{AC}+5.37 \mathrm{BC}+5.96 \mathrm{AB}^{2}-4.74 \mathrm{~A} \mathrm{BC}\end{array}$ & $<0.0001$ & 0.8195 & 0.6571 & 10.407 & 5.05 & 9.28 & 708.14 & 0.9078 \\
\hline & SVI & $+84.05-5.45 \mathrm{~A}-2.20 \mathrm{~B}-3.30 \mathrm{C}+8.25 \mathrm{~B}^{2}+11.00 \mathrm{~A} \mathrm{~B}+2.12 \mathrm{BC}$ & $<0.0001$ & 0.8536 & 0.7861 & 15.181 & 4.87 & 5.52 & 604.66 & 0.8198 \\
\hline \multirow{4}{*}{ UAAASB-mechanical mixing } & sCOD removal & $+81.53+3.70 \mathrm{C}-8.50 \mathrm{AB}-7.75 \mathrm{~A} \mathrm{~B}^{2}-6.00 \mathrm{BC}^{2}+1.50 \mathrm{ABC}$ & $<0.0001$ & 0.9260 & 0.8995 & 24.879 & 2.93 & 3.59 & 240.79 & 0.6317 \\
\hline & TN removal & $+36.71-9.12 \mathrm{~B}+2.74 \mathrm{C}-7.44 \mathrm{~A}+4.14 \mathrm{~B}^{2}-2.27 \mathrm{C}^{2}$ & $<0.0001$ & 0.8858 & 0.8450 & 18.868 & 3.74 & 9.92 & 421.44 & 0.1180 \\
\hline & TP removal & $+45.51-5.19 \mathrm{~B}-4.26 \mathrm{C}-7.43 \mathrm{~A}-8.16 \mathrm{~A}^{2}+2.51 \mathrm{BC}-6.78 \mathrm{AB}$ & $<0.0001$ & 0.8587 & 0.7935 & 12.375 & 4.71 & 11.37 & 911.65 & 0.0228 \\
\hline & SVI & $+87.50-3.78 \mathrm{~B}-3.65 \mathrm{C}-5.05 \mathrm{~A}+8.46 \mathrm{~B}^{2}+1.56 \mathrm{BC}+9.06 \mathrm{AB}$ & 0.0021 & 0.9100 & 0.8685 & 18.929 & 3.45 & 3.76 & 277.99 & 0.0710 \\
\hline
\end{tabular}


Table 7. The optimization criteria for the responses studied.

\begin{tabular}{lll}
\hline Response & Limit & Unit \\
\hline sCOD removal & $\geq 90$ & $\%$ \\
TN removal & $\geq 50$ & $\%$ \\
TP removal & $\geq 50$ & $\%$ \\
SVI & $\leq 90$ & $\mathrm{ml} / \mathrm{g}$ \\
\hline
\end{tabular}

Table 8. Verification experiments at the optimum conditions for the ultrasound-augmented UAAASB.

\begin{tabular}{|c|c|c|c|c|c|c|}
\hline \multirow[t]{2}{*}{ Run } & \multirow[t]{2}{*}{ Conditions } & & \multicolumn{4}{|l|}{ Response } \\
\hline & & & $\begin{array}{l}\text { SCOD } \\
\text { removal, } \\
(\%)\end{array}$ & $\begin{array}{l}\text { TN } \\
\text { removal, } \\
(\%)\end{array}$ & $\begin{array}{l}\text { TP } \\
\text { removal, } \\
(\%)\end{array}$ & $\begin{array}{l}\text { SVI, } \\
(\mathrm{mg} / \mathrm{l})\end{array}$ \\
\hline \multirow[t]{3}{*}{1} & $\begin{array}{l}\text { HRT:12h } \\
\text { Aeration }\end{array}$ & $\begin{array}{l}\text { Experimental } \\
\text { values }\end{array}$ & 92.5 & 51.5 & 54 & 90 \\
\hline & mode: 1.5 & Model values & 92.98 & 55 & 51.79 & 84.93 \\
\hline & $\begin{array}{l}\text { MLSS:5000 } \\
\mathrm{mg} / 1\end{array}$ & Standard deviation & 0.15 & 2.47 & 1.56 & 3.58 \\
\hline \multirow[t]{3}{*}{2} & $\begin{array}{l}\text { HRT: } 15 \mathrm{~h} \\
\text { Aeration }\end{array}$ & $\begin{array}{l}\text { Experimental } \\
\text { values }\end{array}$ & 95 & 55 & 52 & 85 \\
\hline & mode: 2 & Model values & 97 & 50 & 46.03 & 80.15 \\
\hline & $\begin{array}{l}\text { MLSS:4000 } \\
\mathrm{mg} / 1\end{array}$ & Standard deviation & 1.41 & 3.53 & 4.2 & 3.45 \\
\hline
\end{tabular}




\section{Graphical abstract}

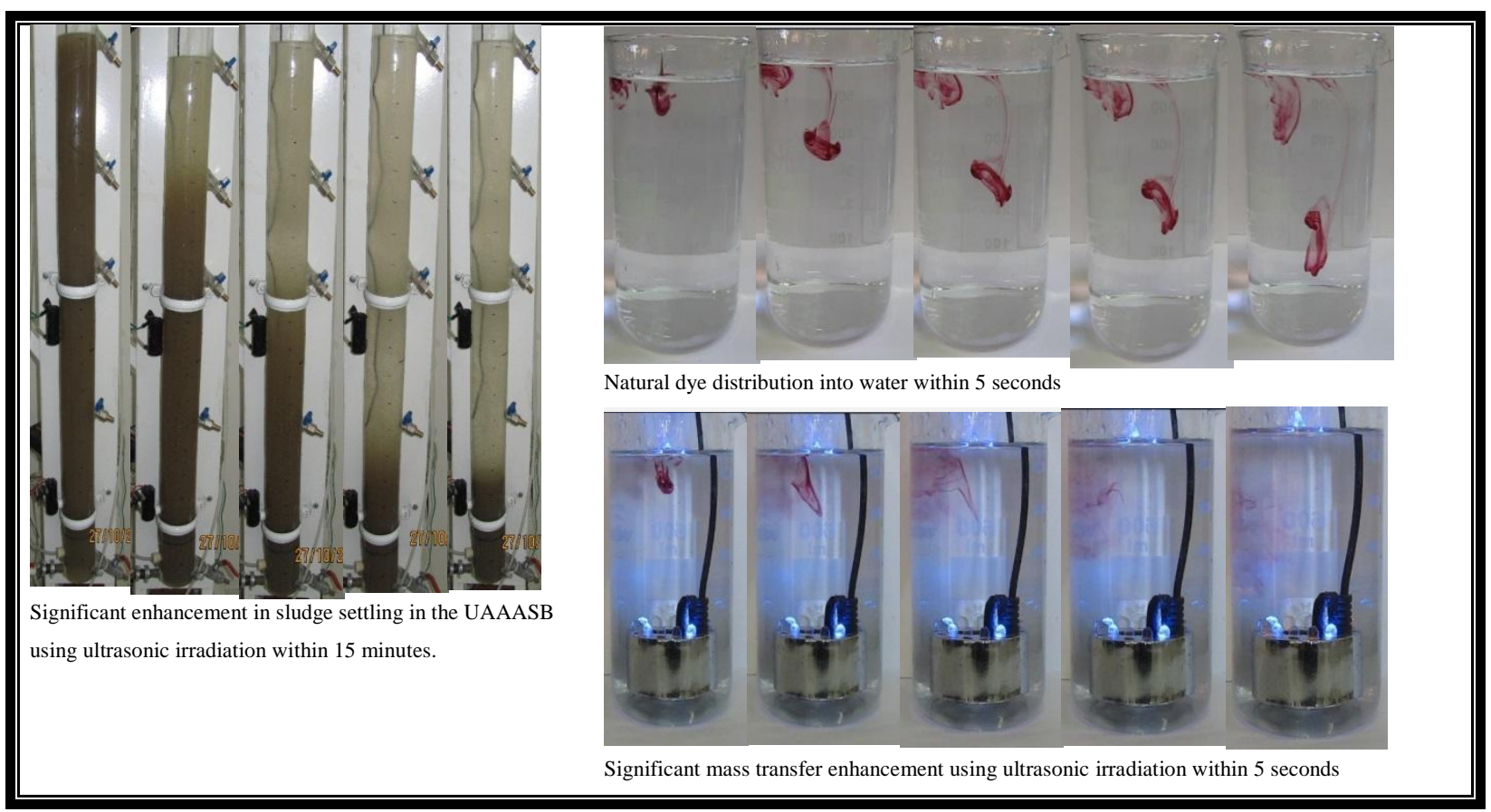

